Draft - Publication Forthcoming in N.Y.U. Review of Law \& Social Change Vol. 42.4

\title{
134,368 UNNAMED WORKERS: CLIENT-CENTERED REPRESENTATION ON BEHALF OF H-2A AGRICULTURAL GUESTWORKERS
}

\author{
Briana Beltran*
}

\begin{abstract}
Each year, tens of thousands of workers, mostly from Mexico and mostly men, enter the United States on temporary visas to labor in its agricultural fields. $H-2 A$ workers, as they are known, are the ultimate outsiders: contracted by a single employer for a specified period, they face dangerous labor and housing conditions, without the option of seeking other employment and with no other ties to or rights in the United States. Despite a robust regulatory scheme that mandates terms including their hourly wage and expenses their employer is required to cover, $H-2 A$ workers are frequently exploited, experiencing everything from wage theft to the extraction of unlawful recruitment fees. To compound the problem, the systems in place to redress these wrongs are woefully insufficient: government enforcement is weak, and $\mathrm{H}-2 \mathrm{~A}$ workers' ability to take direct action is undercut by factors such as their temporary and isolated presence in the United States and the intentional limitations on their rights and access to legal representation under federal law. Despite these constraints, there are examples of $\mathrm{H}-2 \mathrm{~A}$ workers who have filed civil lawsuits against their employers. Having done so, they still encounter obstacles to their full participation in the process, due to the lack of familiarity with the U.S. legal system and the likelihood that the litigation will continue while they are in their home countries.

In this article, I explore strategies for minimizing the disconnect between $\mathrm{H}-2 \mathrm{~A}$ workers and the process of civil litigation, and consider the ways in which litigation itself can be an empowering process and a vehicle for amplifying worker voice. Using the frame of client-centered lawyering, and drawing on two recent case studies of community lawyering among lowwage immigrant workers, I discuss the methods that lawyers representing $H$ -

\footnotetext{
${ }^{*}$ Clinical Teaching Fellow, Farmworker Legal Assistance Clinic, Cornell Law School
} (J.D., New York University School of Law; B.A., Stanford University). Thank you to the members of my small group at the New York University School of Law Clinical Law Review Writers' Workshop for their excellent insights and suggestions for improvement on an early draft of this paper: Deborah Archer, Danielle Pelfrey Duryea, Joseph Pileri, Margaret Reuter, Stephen Rosenbaum, and Colleen Shanahan. Thank you also to my colleagues at Cornell, John Blume, Beth Lyon, and Madalyn Wasilczuk for their feedback and support throughout this process.
\end{abstract}


$2 A$ workers can employ during the various stages of a civil lawsuit in order to ensure that their clients are not again relegated to an outsider status. In particular, I focus on four "moments" in the life of a case: the decision to file a lawsuit, the drafting of the complaint, discovery, and trial. Moreover, I also consider how client voice can be amplified outside of the four corners of a lawsuit, and provide strategies for how to amplify worker voice while settling cases and discuss the downstream, indirect effects of litigation on $\mathrm{H}-2 \mathrm{~A}$ worker empowerment. By putting these considerations into practice, I argue that litigation itself can serve as an empowering experience for $\mathrm{H}-2 \mathrm{~A}$ workers and shed light on the abuses within the H-2A program more generally.

\section{TABLE OF CONTENTS}

I. INTRODUCTION

II. OUTSIDERS WITH NO WAY IN: B ACKGROUND ON THE H-2A PROGRAM AND THE DIFFICULTIES OF REMEDYING THE MISTREATMENT OF H-2A

WORKERS .7

A. OVERVIEW OF THE H-2A PROGRAM............................................... 7

1. The H-2A APPLICATION PROCESS ........................................... 12

2. THE H-2A PrograM's SubSTANTIVE PRovisions..................16

A. SubStantive Protections FOR H-2A WORKERS ...........17

B. The TRUE INTENDED BENEFICIARIES OF THE SubSTANTIVE PROTECTIONS

C. The UtTer Failure OF the Substantive PROTECTIONS ...........................................................2 21

B. LIMITED RIGHTS AND COMPLICATED REMEDIES .............................24

1. COMPLiCATIONS With THE Client BASE..............................24

A. Cultural AND Linguistic BarRIERS ..........................25

B. Limited And Isolated Physical PResence IN United STATES ..................................................................2 27

C. UNIQUELY VULNERABLE TO RETALIATION ......................29

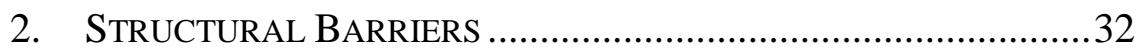

A. WEAK GOVERNMENT ENFORCEMENT .............................32

B. RESTRICTIONS ON COUNSEL'S SCOPE OF

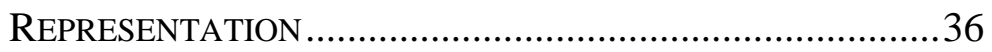

C. LIMITED LEGAL ClAIMS ................................................39

III. A VISION OF REPRESENTATION FOR H-2A WORKERS IN CIVIL LITIGATION

A. Existing VIEWS OF Litigation IN LOW-WAgE WORKER

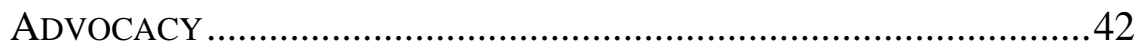

B. VOICE AND EMPOWERMENT IN LITIGATION ....................................49

1. TAKING LEGAL ACTION .......................................................51

2. FILING THE COMPLAINT........................................................54 


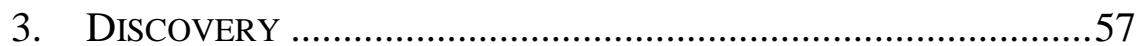

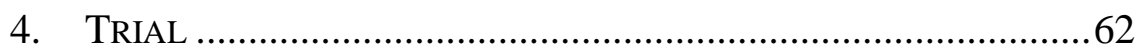

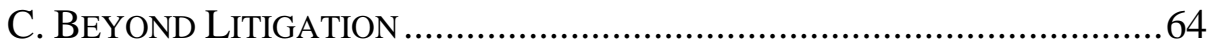

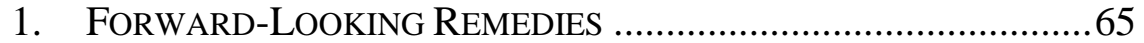

2. INDIRECT EFFECTS OF LITIGATION ........................................68

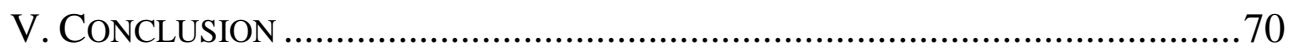




\section{INTRODUCTION}

In 2013, more than a dozen workers from the Mexican state of Oaxaca entered the United States on H-2A visas to work for a tobacco farmer in rural Kentucky. ${ }^{1}$ Already in debt due to loans they had taken out to pay for predeparture expenses, the workers soon learned that they had to pay $\$ 2,000$ for their visas and still more for rent and additional costs of transporting them to the farm. ${ }^{2}$ They were required to pay these charges via cash kickbacks to their supervisor throughout the season, reducing their already-low wages even further below the federally-mandated rates. ${ }^{3}$ All of this is illegal, expressly prohibited by the regulations governing the $\mathrm{H}-2 \mathrm{~A}$ program. ${ }^{4}$

When the U.S. Department of Labor ("DOL") came to investigate the allegations, the workers' supervisor, together with employees of the immigration law firm the employer had hired to file the applications to import the workers, pressured the workers to lie about these conditions to investigators, under threat of canceling their visas and sending them back to Mexico. ${ }^{5}$ In the end, U.S. DOL did not recover any funds for the workersit collected a total of $\$ 6,300$ in reduced fines from the employer and did not hold the law firm responsible for any of the violations. ${ }^{6}$ The employer continued to bring in H-2A workers under the program in subsequent years. ${ }^{7}$ In the absence of a remedy from U.S. DOL, a group of the workers filed a federal lawsuit against the employer and the law firm in $2015 .^{8}$

These Kentucky tobacco workers are among the hundreds of thousands ${ }^{9}$ of workers who have entered the United States on H-2A visas, serving as temporary participants in the American agricultural system-

\footnotetext{
${ }^{1}$ John Cheves, How a Scott County tobacco farm allegedly mistreated workers from Mexico, LEXINGTON HERALD LEADER, Aug. 8, 2015, http://www.kentucky.com/news/local/watchdog/article44614560.html.

${ }^{2}$ Deborah Yetter, Lawsuits allege migrant workers exploited, THE COURIER JOURNAL (Louisville, Ky.), May 29, 2015, https://www.courierjournal.com/story/news/local/2015/05/29/lawsuits-allege-migrant-workersexploited/28174377/.

${ }^{3}$ Cheves, supra note 1.

${ }^{4}$ See infra section II(A)(1)(a).

${ }^{5}$ Cheves, supra note 1.

${ }^{6} \mathrm{Id}$.

${ }^{7}$ Id.

${ }^{8}$ Yetter, supra note 2 . The case has since been resolved. See Order of Dismissal, CruzCruz v. McKenzie Farms, No. 05:15-cv-157 (E.D. Ky. Sept. 5, 2017).

${ }^{9}$ There is no way to know precisely how many individuals have worked as $\mathrm{H}-2 \mathrm{~A}$ workers in the United States, particularly since the same individual may return to the United States multiple times. However, with the program having been in existence for three decades and the annual number of visas issued now approaching 200,000, see infra notes 25-40 and accompanying text, this is a reasonable estimate.
} 
filling jobs that their employers assert no American workers are willing to take, and lacking any long-term legal ties to or rights in the United States. They are also among the significant number of $\mathrm{H}-2 \mathrm{~A}$ workers who have experienced blatant workplace abuses.

Deciding to speak out, as the Kentucky tobacco workers did, is not an insignificant decision. H-2A workers may only work for the employer who has requested their labor, ${ }^{10}$ are often in debt before arriving to the United States, ${ }^{11}$ and are frequently victims of retaliation or blacklisting if they complain about mistreatment. ${ }^{12}$ In short, it is entirely rational to stay quiet. For those workers who make the difficult choice to speak out and take their employers ${ }^{13}$ to court, they are likely to then face a second uphill battle. During the course of litigation, H-2A workers remain at the margins in many respects: the U.S. legal system may be utterly foreign to them and their lack of presence in the United States during litigation can render the process of litigation confusing and inaccessible. ${ }^{14}$ Pursuing remedies for violations of their rights, therefore, poses the risk of reinforcing-rather than diminishing- $-\mathrm{H}-2 \mathrm{~A}$ workers' sense of being outsiders.

Litigation need not be this way, however. Numerous social justiceminded practitioners over the years have written extensively about how attorneys representing marginalized communities can approach such representation in a client-centered manner. Offering "an alternative vision of lawyering that conceptualize[s] legal representation primarily in problemsolving terms and redefine[s] the boundaries of decision-making authority in the lawyer-client relationship," 15 the client-centered lawyering model

\footnotetext{
${ }^{10}$ Observers have made outright comparisons between the $\mathrm{H}-2 \mathrm{~A}$ and other guestworker programs and slavery. See, e.g., Mary L. Hall, Defending the Rights of H-2A Farmworkers, 27 N.C. J. INT'L L. \& COM. REG. 521, 536 (2001) (noting that non-H-2A farmworkers, even undocumented workers, often describe H-2A workers as being "like slaves"); S. POVERTY LAW CTR., Close tO SLAVERY: GUESTWORKER PROGRAMS IN THE UNITED STATES 1 (2013), available https://www.splcenter.org/sites/default/files/d6_legacy files/downloads/publication/SPLCClose-to-Slavery-2013.pdf [hereinafter CLOSE TO SLAVERY] (quoting Congressman Charles Rangel as having stated, "This guestworker program's the closest thing I've ever seen to slavery.").

${ }^{11}$ See infra notes 103-102, 124-127 and accompanying text.

12 See infra notes 128-129 and accompanying text.

13 Though I use the term "employers," defendants in H-2A lawsuits are not always limited to the direct employers, and can include recruiters, joint employers, and other agents of the true "employer."

${ }^{14}$ See infra sections II(B)(1)(a)-(b).

15 Katherine R. Kruse, Fortress in the Sand: The Plural Values of Client-Centered Representation, 12 CLINICAL L. REV. 369, 376 (2006); see also Ascanio Piomelli, Appreciating Collaborative Lawyering, 6 CLINICAL L. REV. 427, 437 (2000) (describing "primary concern" of model as "ensur[ing] that clients play the central role not only in setting ultimate objectives but also in making important decisions" and that "model viewed
} 
emphasizes the client - the person who must live with the consequences and who best understands her own values - as the decisionmaker, rather than the lawyer. ${ }^{16}$ Relatedly, other scholars have written about the importance of honing cross-cultural lawyering skills, in order to more fully understand the client's situation and the biases that even well-intentioned lawyers may bring to the table. ${ }^{17}$ Building on the client-centered tradition, in more recent years, other advocates have applied many of these lessons in the context of representing communities and broader social movements. Often referred to as community lawyering, such lawyers place the community or movement first, with the lawyers playing a supporting role in the task of advocating for and empowering the individuals whose rights are at stake. ${ }^{18}$

Applying these lessons in the context of representing H-2A workers may seem intimidating, particularly with clients who face such significant access to justice issues. However, these difficulties do not mean that the lessons of client-centered lawyering and its brethren need to be thrown out the window entirely. On the contrary, civil litigation on behalf of $\mathrm{H}-2 \mathrm{~A}$ workers provides numerous opportunities to apply such principles. This paper is an effort to explore those opportunities. In the discussion that follows, I consider the various ways in which advocates can be faithful to the goals of the social justice-minded practitioners in the client-centered and community lawyering movements, but in what would otherwise be a difficult context for applying such principles: litigating civil claims on behalf $\mathrm{H}-2 \mathrm{~A}$ workers.

I begin, in Part II, by providing an overview of the H-2A program, from the process of applying for $\mathrm{H}-2 \mathrm{~A}$ workers, to the protections theoretically offered to such workers, and concluding with a detailed look at

lawyering primarily as problem-solving"); Binny Miller, Give Them Back Their Lives: Recognizing Client Narrative in Case Theory, 93 MICH. L. REV. 485, 503 (1994) (describing model as one in which "lawyers should interact with clients in a way that allows clients to make decisions about themselves"); Robert D. Dinerstein, Client-Centered Counseling: Reappraisal and Refinement, 32 ARIZ. L. REV. 501,507 (1990) (“Client-centered counseling may be defined as a legal counseling process defined to foster client-decisionmaking.").

${ }^{16}$ See Kruse, supra note 15, at 402; see also Dinerstein, supra note 15, at 549 (client as decisionmaker increases likelihood that decisions will accord with client's values).

17 Susan Bryant and Jean Koh Peters, in particular, were at the forefront of such scholarship. As Bryant states in an article documenting their collaborative project that led to the establishment of the "five habits" of cross-cultural lawyering: "[A] competent crosscultural lawyer acknowledges racism, power, privilege and stereotyped thinking as influencing her interactions with clients and case planning, and works to lessen the effect of these pernicious influences." Susan Bryant, The Five Habits: Building Cross-Cultural Competence in Lawyers, 8 CLINICAL L. REV. 33, 55 (2001); see also Michelle S. Jacobs, People from the Footnotes: The Missing Element in Client-Centered Representation, 27 GOLDEN GATE U. L. REV. 345, 405-11 (1997) (calling for increased cross-cultural training in clinical legal education).

${ }^{18}$ See infra section III(A). 
the ways in which such workers face significant hurdles in accessing remedies for violations of their rights. In Part III, I turn to a vision for representing $\mathrm{H}-2 \mathrm{~A}$ workers in a client-centered manner during the course of civil litigation. I first discuss two case studies of community lawyering with low-wage workers and the role litigation played in such examples. I then examine litigation from two perspectives. First, I take a detailed look at the process of litigation itself and how an attorney can approach the various phases of a lawsuit in a client-centered manner. I then consider the ways in which a client-centered approach can extend beyond the lawsuit, and address the opportunity to pursue forward-looking remedies in settlement of cases as well as the empowering effect that a lawsuit can have on $\mathrm{H}-2 \mathrm{~A}$ workers more generally.

\section{OUTSIDERS WITH NO WAY IN: B ACKGROUND ON THE H-2A PROGRAM AND THE DiFFICULTIES OF REMEDYING THE MISTREATMENT OF H-2A WORKERS}

Below, I begin by providing an overview of the $\mathrm{H}-2 \mathrm{~A}$ program and an explanation of the numerous reasons why $\mathrm{H}-2 \mathrm{~A}$ workers face a uniquely complicated situation in terms of pursuing legal remedies for violations of their rights.

\section{A. Overview of the H-2A Program}

Guestworker programs have existed in the United States since World War I, but the modern incarnations took shape in 1986, with the passage of the Immigration and Reform Control Act ("IRCA"). ${ }^{19}$ IRCA split what was

\footnotetext{
${ }^{19}$ For a general background on guestworker programs in the United States, including historical context on agricultural labor and immigration policy before the first formal programs, see Hall, supra note 10, at 527-28; Michael Holley, Disadvantaged by Design: How the Law Inhibits Agricultural Guest Workers from Enforcing Their Rights, 18 HOFSTRA LAB. \& EMP. L.J. 575, 581-91 (2001); U.S. GENERAL ACCOUNTING OFFICE REPORT TO CONGRessional CommitTEes, H-2A Agricultural Guestworker Program: Changes Could Improve Services to Employers and Better Protect Workers 18-19 (Dec. 31, 1997), available at http://www.gao.gov/archive/1998/he98020.pdf; JUSTICE IN MOTION, U.S. TEMPORARY FOREIGN WORKER VISAS, H-2A VISA 5-7 (Nov. 2015), available at https://static1.squarespace.com/static/57d09e5c5016e1b4f21c9bd3/t/58c328fac534a58f937 efd4e/1489185020017/VisaPages_H2A_2015update.pdf [hereinafter JUSTICE IN MOTION, H-2A Visa]; FarmWorker Justice, No Way to Treat A Guest: Why the H-2A Agricultural VisA PROGRAM FAILs U.S. AND FOREIGN WORKERS 12-13 (2011), available at

https://www.farmworkerjustice.org/sites/default/files/documents/7.2.a.6\%20No\%20Way\% 20To\%20Treat\%20A\%20Guest\%20H-2A\%20Report.pdf [hereinafter No WAY TO TREAT A Guest]; ClOSE TO SLAVERY, supra note 10, at 3-5. For the ways in which the World War II-era Bracero and early Caribbean visa programs were characterized by significant
} 
once a general guestworker program into two: the H-2A visa now existed for agricultural work specifically, while the $\mathrm{H}-2 \mathrm{~B}$ visa became a guestworker visa for non-agricultural work. ${ }^{20}$ While the $\mathrm{H}-2 \mathrm{~B}$ program is subject to an annual cap, ${ }^{21}$ the number of $\mathrm{H}-2 \mathrm{~A}$ visas that the government can approve each year are unlimited.

The two new versions of the H-2 program began modestly: in 1987, the first year of the program, the government issued only $44 \mathrm{H}-2 \mathrm{~A}$ visas and $62 \mathrm{H}-2 \mathrm{~B}$ visas. $^{22}$ The programs expanded shortly thereafter: between 1988

mistreatment of workers, despite ostensible labor and contractual protections, see Annie Smith, Imposing Injustice: The Prospect of Mandatory Arbitration for Guestworkers, 40 N.Y.U. REV. L. \& SOC. CHANGE 375, 381 (2016) (“Among the abuses experienced by these early guestworkers were extremely poor living conditions, unpaid wages, physical abuse, and lack of access to medical treatment."); CLOSE TO SLAVERY, supra note 10, at 4 (because many workers did not speak English, they "were often unaware of contractual guarantees," and many employers often "shortchang[ed] workers"); No WAY TO TREAT A GUEST, supra, at 12 (problems included wage theft, "deplorable" housing, unsafe transportation, denial of healthcare, and few workers would complain "because they were tied to a single employer, and renewal of their contract depended on the employer's good will").

${ }^{20}$ See Smith, supra note 19, at 381; ClOSE TO SlaVery, supra note 10, at 5; No WAY TO TREAT A GUEST, supra note 19, at 13.

${ }^{21} \mathrm{H}-2 \mathrm{~B}$ visas are limited by statute to 66,000 per fiscal year. See U.S. CITIZENSHIP AND

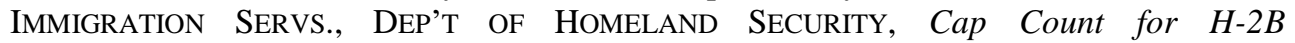
Nonimmigrants, https://www.uscis.gov/working-united-states/temporary-workers/h-2bnon-agricultural-workers/cap-count-h-2b-nonimmigrants (last visited Nov. 29, 2017). However, in 2017, the Department of Homeland Security approved a one-time increase in the cap, adding an additional 15,000 visas for the year. See U.S. CITIZENSHIP AND ImMigration Servs., DeP'T of Homeland Security, One-Time Increase in $H-2 B$ Nonimmigrant Visas for FY 2017, https://www.uscis.gov/working-united-states/temporaryworkers/one-time-increase-h-2b-nonimmigrant-visas-fy-2017 (last visited Nov. 29, 2017); see also Daniel Kowalski, H-2B Visas and the Making of an 'Ultra Vires' Regulation, LAw360, July 25, 2017, https://www.law360.com/articles/947267/h-2b-visas-and-themaking-of-an-ultra-vires-regulation (summarizing 2017 increase in cap and "returning worker exemption" that had, in the past, allowed for exemptions from the cap in certain circumstances).

${ }^{22}$ See U.S. DeP'T of STATE, Classes of Nonimmigrants Issued Visas (Detailed Breakdown) (Including Crewlist Visas and Border Crossing Cards), Fiscal Years 19871991, $\quad$ https://travel.state.gov/content/dam/visas/Statistics/Non-ImmigrantStatistics/NIVClassIssuedDetailed/NIVClassIssued-DetailedFY1987-1991.pdf (last visited July 3, 2017) [hereinafter Nonimmigrants Issued Visas 1987-1991]. Commentators have observed the challenges in determining the exact number of H-2A workers actually in the United States each year, given the numerous governmental agencies that play a role in the application and approval process and the resulting variation in statistics from each source. See Justice IN Motion, H-2A VISA, supra note 19, at 15-17; see also DANIEL Costa \& JENNIFER ROSENBAUM, ECONOMIC POLICY INSTITUTE, TEMPORARY FOREIGN WORKERS BY THE NUMBERS: NEW ESTIMATES BY VISA CLASSIFICATION 8-10 (March 7, 2017), available at http://www.epi.org/files/pdf/120773.pdf. However, data from the U.S. Department of State ("State Department") about the number of visas it issues to individuals is generally regarded as "giv[ing] perhaps the best idea of how many foreign H-2A workers may enter the U.S. in 
and 1991, the H-2A program increased by approximately 1,000 workers annually, going from 2,612 workers to 6,487 workers. ${ }^{23}$ The H-2B program similarly increased in size in those initial years, from 683 workers in 1988, to 9,575 workers in 1989 , and increasing to 14,573 in $1991 .^{24}$

Given that the H-2A program is not subject to a numerical cap, it was free to expand without any constraints. And expand it has. The growth has been not just in overall numbers, but also the geographic scope of the program. In terms of total numbers, the size of the $\mathrm{H}-2 \mathrm{~A}$ program increased more than twelve times in the two decades between 1996 and 2016: in 1996, there were approximately 11,000 H-2A visas issued, while 2016 saw over $134,000 \mathrm{H}-2 \mathrm{~A}$ visas issued. ${ }^{25}$ Even more startling is the fact that the H-2A program more than doubled in size between 2012 and 2016 alone: in 2012, the government issued $65,345 \mathrm{H}-2 \mathrm{~A}$ visas; four years later, that number had shot up to 134,368 visas. ${ }^{26}$ Notably, some of this increase has been into sectors that are not traditionally "temporary or seasonal," as H-2A jobs are supposed to be; ranchers in the west have successfully lobbied to bring in $\mathrm{H}$ 2A sheepherders, and the dairy industry is attempting to do the same, claiming the need to do so based on the all-too-familiar refrain of labor shortages. ${ }^{27}$ Most of the tens of thousands of visas issued annually are being

any given year.” JUSTICE IN MotiON, H-2A VISA, supra note 19, at 16. I therefore generally (unless otherwise noted) refer to such figures from the State Department, which identify the number of visas issued in a given period.

${ }^{23}$ See Nonimmigrants Issued Visas 1987-1991, supra note 22.

${ }^{24}$ See id.

25 See, e.g., Muzaffar Chishti \& Jessica Bolter, Migration PoliCy InST., Despite Political Resistance, Use of Temporary Worker Visas Rises as U.S. Labor Market Tightens (June 20, 2017), http://www.migrationpolicy.org/article/despite-political-resistance-usetemporary-worker-visas-rises-us-labor-market-tightens (documenting increase from 11,000 to 134,000 H-2A workers between 1996 and 2016).

${ }^{26}$ See U.S. DEP'T OF STATE, Nonimmigrant Visas Issued by Classification (Including Border Crossing Cards), Fiscal Years 2012-2016, https://travel.state.gov/content/dam/visas/Statistics/AnnualReports/FY2016AnnualReport/F Y16AnnualReport-TableXVIB.pdf (last visited June 27, 2017).

${ }^{27}$ See No Way to TREAT A GuESt, supra note 19, at 32-35; see also Kelcee Griffis, Immigration Bill Roundup: Visa Extensions, H-1B Reforms, LAw360, May 1, 2017, https://www.law360.com/articles/919056/immigration-bill-roundup-visa-extensions-h-1breforms (noting introduction of H.R. 2087 in Congress by Rep. Sean Duffy of Wisconsin, which would allow dairy workers to be admitted under the H-2A program for up to 18 months). Though not typical, dairy farms have been able to bring in workers in the past. See, e.g., Matthew Bultman, Dairy Farm Wins H-2A Approval For Farm Manager Jobs, LAw360, Jan. 28, 2016, https://www.law360.com/articles/752038 (summarizing decision by an Administrative Law Judge, reversing the decision by DOL and allowing a Missouri dairy farm to bring in two guestworkers for manager positions during a ten-month long milking season, originally proposed to be eleven months long, which the judge determined to be "seasonal" work). 
issued to men ${ }^{28}$ of Mexican nationality. ${ }^{29}$

A look at the state-by-state breakdown, summarized in the table that follows, illustrates the larger trend, as well as specific regional growth. According to U.S. DOL, the ten states with the most $\mathrm{H}-2 \mathrm{~A}$ positions certified $^{30}$ in 2010 included six southern states (North Carolina, Louisiana, Georgia, Kentucky, Florida, and Arkansas), plus a trio of states from the west (California, Arizona, and Washington), and New York. Four years later, five of those southern states remained in the top ten, each showing increased numbers in certifications, while western states showed even larger increases in certifications: California increased by $130 \%$, and Washington increased the most, 201\%. By 2017, the same five southern states were in the top ten, though their rankings had changed: Florida and Georgia overtook North Carolina for the states with the most certifications, showing an increase in $461 \%$ and $321 \%$, respectively, as compared to the 2010 statistics. California and Washington also continued to grow at significant rates, increasing their numbers by close to five times those of 2010. Most dramatically, the newcomer to the list, Michigan (ranked ninth), showed an astounding jump from just 277 certified positions in 2010 to 6,432 positions in 2017 -an increase of 2,222\% over those seven years. In all, half of the top ten states in 2017-Florida, Georgia, Washington, California, and Michigan-grew at rates that outpaced the national increase of $153 \%$ between 2010 and 2017.

\footnotetext{
${ }^{28}$ The United States government does not release data breaking down $\mathrm{H}-2 \mathrm{~A}$ visa holders by age and sex, but it is common knowledge that H-2A workers are largely young men. See No WAy to TREAT A GUEST, supra note 19, at 26 (observing that "it is well known that women and older adults are basically absent from the H-2A program"). This is because it is the clear preference of employers. See id. at 17 (noting employers' ideal workforce as being "mostly young men removed from daily family obligations who will work long hours for low pay"); see also CLOSE TO SLAVERY, supra note 10, at 32 ("[T] he ability to choose the exact characteristics of a worker (male, age 25-40, Mexican, etc.) is one of the very factors that make guestworker programs attractive to employers."). For a recent report documenting the systematic sex-based discrimination in the various guestworker programs, see CENTRO De los Derechos del Migrante \& Univ. of Pa. LaW Sch. Transnational Legal Clinic, Engendering ExPloitation: Gender INEQUality in U.S. LABOR MigRATION PROGRAMS (2017), available at http://www.cdmigrante.org/wpcontent/uploads/2017/09/Engendered-Exploitation.pdf.

${ }^{29}$ In FY2016, 123,231 (91.71\%) of H-2A visas went to Mexican nationals. See U.S. DEP'T OF STATE, FY 2016 Nonimmigrant Visas Issued, https://travel.state.gov/content/dam/visas/Statistics/Non-ImmigrantStatistics/NIVDetailTables/FY16\%20NIV\%20Detail\%20Table.pdf (last visited June 27, 2017).

${ }^{30}$ As I note in the text, the discussion focuses on the number of positions certified by the U.S. DOL, which differs from the number of visas issued by the State Department. This is in part because of a limitation of the State Department data. While likely more accurate, see supra note 22 , it does not provide a breakdown of the visas by state, whereas U.S. DOL data regarding certifications does provide such a breakdown.
} 


\begin{tabular}{|l|c|c|c|c|c|c|c|c|}
\hline \multicolumn{1}{|c|}{ STATE } & FY2010 & \multicolumn{3}{c|}{ FY2014 } & \multicolumn{3}{c|}{ FY2017 } \\
\hline & Cert. $^{31}$ & $R$ & Cert. $^{32}$ & $R$ & Change $^{33}$ Cert. $^{33}$ & $R$ & Change \\
\hline N. Carolina & 9,387 & 1 & 14,502 & 1 & $54 \%$ & 20,713 & 3 & $121 \%$ \\
\hline Louisiana & 6,981 & 2 & 7,222 & 5 & $3 \%$ & 8,875 & 6 & $27 \%$ \\
\hline Georgia & 5,561 & 3 & 10,387 & 3 & $87 \%$ & 23,421 & 2 & $321 \%$ \\
\hline Kentucky & 5,455 & 4 & 6,755 & 6 & $24 \%$ & 7,403 & 7 & $36 \%$ \\
\hline Florida & 4,510 & 5 & 13,544 & 2 & $200 \%$ & 25,303 & 1 & $461 \%$ \\
\hline Arizona & 4,309 & 6 & 3,745 & 9 & $-13 \%$ & 6,060 & 10 & $41 \%$ \\
\hline New York & 3,858 & 7 & 4,676 & 8 & $21 \%$ & 6,870 & 8 & $78 \%$ \\
\hline Washington & 3,014 & 8 & 9,077 & 4 & $201 \%$ & 18,535 & 4 & $515 \%$ \\
\hline Arkansas & 3,006 & 9 & $2,519^{34}$ & $*$ & $-16 \%$ & $* 35$ & $*$ & $*$ \\
\hline California & 2,629 & 10 & 6,043 & 7 & $130 \%$ & 15,232 & 5 & $479 \%$ \\
\hline Virginia & 2,455 & $*$ & 3,216 & 10 & $31 \%$ & $*$ & $*$ & $*$ \\
\hline Michigan & $277^{36}$ & $*$ & $1,317^{37}$ & $*$ & $375 \%$ & 6,432 & 9 & $222 \%$ \\
\hline National & $79,011^{38}$ & $*$ & 116,689 & $*$ & $48 \%$ & 200,049 & $*$ & $153 \%$ \\
\hline \multicolumn{8}{|c|}{ Cert. $=$ Number of Positions Certified } \\
\hline
\end{tabular}

\footnotetext{
${ }^{31}$ Unless otherwise noted, data in this column is from NO WAY TO TREAT A GUEST, supra note 19, at 19 (Figure 2).

${ }^{32}$ Unless otherwise noted, data in this column is from OFFICE OF FOREIGN LABOR Certification, EMPlOyment \& Training AdMin., U.S. DeP'T OF LABOR, H-2A Temporary Agricultural Labor Certification Program - Selected Statistics, FY 2014, https://www.foreignlaborcert.doleta.gov/pdf/H-2A_Selected_Statistics_FY2014_Q4.pdf (last visited Nov. 27, 2017).

${ }^{33}$ Unless otherwise noted, data in this column is from OFFICE OF FOREIGN LABOR CertificAtion, EMPloyment \& Training ADMin., U.S. DEP'T OF LABOR, H-2A Temporary Agricultural Labor Certification Program - Selected Statistics, FY 2017, https://www.foreignlaborcert.doleta.gov/pdf/PerformanceData/2017/H2A_Selected_Statistics_FY2017.pdf (last visited Nov. 27, 2017).

${ }^{34}$ See OFFICE OF FOREIGN LABOR CERTIFICATION, EMPLOYMENT \& TRAINING ADMIN., U.S. DEP'T OF LABOR, 2014 Annual Report, Appendix A: State Employment-Based Immigration Profiles, Arkansas, https://www.foreignlaborcert.doleta.gov/map/2014/AR.pdf (last visited Nov. 27, 2017).

${ }^{35}$ State-by-state individual summaries for FY 2017 outside of the top ten states.

${ }^{36}$ See OFFICE OF FOREIGN LABOR CERTIFICATION, EMPLOYMENT \& TRAINING ADMIN., U.S. DEP'T OF LABOR, Foreign Labor Certification Annual Report, October 1, 2009 September 30, 2010, $\quad$ at A-24 https://www.foreignlaborcert.doleta.gov/pdf/OFLC 2010_Annual_Report_Master.pdf (last visited Nov. 27, 2017) [hereinafter OFLC 2010 ANNUAL REPORT].

${ }^{37}$ See OFFICE OF Foreign LABOR CERTIFICATION, EMPlOYMENT \& TRAining Admin., U.S. DEP'T OF LABOR, 2014 Annual Report, Appendix A: State Employment-Based Immigration Profiles, Michigan, https://www.foreignlaborcert.doleta.gov/map/2014/MI.pdf (last visited Nov. 27, 2017).

${ }^{38}$ See OFLC 2010 ANNUAL REPORT, at 31. Of note, 2010 represented a slight drop in the increase of certifications. In 2008, 82,099 positions were certified, and 86,014 positions were certified in 2010. In light of this, the results are certainly different than if the comparisons had been based on 2009 data, though the increases seen by 2014 and 2017 are so great, the overall trend is clear.
} 
Focusing in on the current moment, it appears that the trend may be even more dramatic. In the first quarter of 2017, U.S. DOL certified 69,272 $\mathrm{H}-2 \mathrm{~A}$ positions alone; this marks a startling $36 \%$ increase from the same period in 2016, when 50,887 positions were approved. ${ }^{39}$ Typical increases in past years have hovered between ten and twenty percent. ${ }^{40}$ This increase is all against the backdrop of an administration that openly supports guestworker programs, as a matter of policy ${ }^{41}$ as well as personal preference. $^{42}$

With this background and brief snapshot of the current status of the $\mathrm{H}-2 \mathrm{~A}$ program in mind, I will delve into the substance of the program in more detail. In the following sections, I will first examine the application process that employers and workers must navigate in order to obtain $\mathrm{H}-2 \mathrm{~A}$ visas, and then provide an overview of the substantive rights afforded to $\mathrm{H}-2 \mathrm{~A}$ workers and the ways in which those rights are flagrantly violated.

\section{The H-2A Application Process}

Though $\mathrm{H}-2 \mathrm{~A}$ workers are the individuals whose labor is sought to harvest American crops, they are largely outsiders in the process that gets them from their homes to the agricultural fields in this country. Employers are the ones who control the process, filing applications with not one, but two

\footnotetext{
${ }^{39}$ See Dan Charles, Government Confirms A Surge In Foreign Guest Workers on U.S. Farms, NAT'L PUB. RADIO, May 18, 2017, http://www.npr.org/sections/thesalt/2017/05/18/528948143/government-confirms-a-surgein-foreign-guest-workers-on-u-s-farms.

${ }^{40}$ See id.

41 See, e.g., Dan Wheat, H-2A progress, appointment raise hopes for ag, reps say, $\begin{array}{llll}\text { CAPITAL PRESS, May 2017, } & \text { 9, }\end{array}$ http://www.capitalpress.com/Nation_World/Nation/20170509/h-2a-progress-appointmentraise-hopes-for-ag-reps-say (summarizing statement of Ray Starling, of the President's Council of Economic Advisers, that the President "will be looking carefully at how to improve or expand the H-2A-visa program"). At the same time, the new U.S. DOL purports to be taking "actions to increase protections of American workers while more aggressively confronting entities committing visa program fraud and abuse." Press Release, U.S. DEP'T OF LABOR, US Secretary of Labor Protects Americans, Directs Agencies to Aggressively Confront Visa Program Fraud and Abuse (June 6, 2017), https://www.dol.gov/newsroom/releases/opa/opa20170606.

${ }^{42}$ Donald Trump and his numerous personal and family-owned businesses have employed both H-2A and H-2B workers in the past. As recently as early 2017, Trump Winery in Virginia applied for more than two dozen H-2A workers, and Trump's properties in New York and Florida have sought to bring in H-2B guestworkers to fill positions as wait staff and house cleaners, among others. See Sam Dangremond, Donald Trump Secures 70 Visas for Foreign Workers at Mar-a-Lago, TOWN \& COUNTRY, Nov. 6, 2017, http://www.townandcountrymag.com/society/politics/a13387745/donald-trump-mar-alago-foreign-workers/.
} 
federal agencies, holding out their compliance with numerous rules and regulations along the way.

The first step in this process involves U.S. DOL. As the governing regulations state, a putative $\mathrm{H}-2 \mathrm{~A}$ employer is required to "demonstrate" to U.S. DOL "that there are not sufficient U.S. workers able, willing, and qualified to perform the work in the area of intended employment at the time needed and that the employment of foreign workers will not adversely affect the wages and working conditions of U.S. workers similarly employed." 43 To do so, the employer submits a "job order" 44 to a state-level entity, known as the state workforce agency, between sixty and seventy-five days before the date the employer anticipates needing workers; the agency then puts the job order into "intrastate clearance" to begin recruitment of U.S. workers. ${ }^{45}$ The agency must refer "each qualified U.S. worker" who applies for the job to the employer. ${ }^{46}$ Also during this time period, the employer must engage in "positive recruitment" 47 of U.S. workers, including running two newspaper advertisements for the job ${ }^{48}$ and clearly documenting any interviews with interested workers, including the reasons why a particular worker does not ultimately take the job. ${ }^{49}$ Within approximately a month, ${ }^{50}$ U.S. DOL is to determine whether the employer has satisfied the requirements as outlined above; if so, the employer's application is certified by U.S. DOL, and the

${ }^{43} 20$ C.F.R. $\$$ 655.103(a); see also 8 U.S.C. $\$ 1188$ (a) (outlining conditions for approval of $\mathrm{H}-2 \mathrm{~A}$ petitions).

44 The employer is to use a U.S. DOL Form, ETA-790, which is a template form requiring the would-be employer to provide numerous details about the terms and conditions of the proposed job. See EMPloyment And Training AdMin., U.S. DeP'T OF LABOR, Agricultural and Food Processing Clearance Order ETA Form 790, https://www.foreignlaborcert.doleta.gov/pdf/ETA_Form_790.pdf (last visited July 6, 2017) [hereinafter ETA Form 790].

4520 C.F.R. $\$ \S 655.121(\mathrm{a}),(\mathrm{c})$.

${ }^{46}$ Id. $\S 655.150(\mathrm{~b})$.

47 The regulations define the term "positive recruitment" as follows:

The active participation of an employer or its authorized hiring agent, performed under the auspices and direction of the [Office of Foreign Labor Certification, designee of the Secretary of Labor for the purposes of this process], in recruiting and interviewing individuals in the area where the employer's job opportunity is located and any other State designated by the Secretary as an area of traditional or expected labor supply with respect to the area where the employer's job opportunity is located, in an effort to fill specific job openings with U.S. workers.

Id. $\S 655.103(\mathrm{~b})$.

${ }^{48}$ See id. $\$ \S 655.151,655.152$.

${ }^{49}$ See id. $\$ 655.156$.

${ }^{50}$ Specifically, this is to occur "no later than 30 calendar days before the date of need" given by the employer for the workers in the application. Id. $\S 655.160$. 
employer proceeds to the next step in the process. ${ }^{51}$

With such approval from U.S. DOL in hand, the employer then turns to the Department of Homeland Security ("DHS") to file visa petitions-I129 Forms - for his workers. ${ }^{52}$ While regulations impose additional requirements to prove that a certain would-be worker is "qualified" for the job, ${ }^{53}$ in practice, such requirements are rarely applicable in this context. That is because those requirements only apply to workers who are named as "beneficiaries" on the I-129s, and DHS regulations do not even require that beneficiaries of petitions for $\mathrm{H}-2 \mathrm{~A}$ visas be named. ${ }^{54}$ Would-be $\mathrm{H}-2 \mathrm{~A}$ workers are, at this point, literally nameless. ${ }^{55}$

Once the visa petition has been approved, the individual workers finally enter the picture. Most workers learn of job opportunities in the United States via recruiters who operate on the ground in sending countries; recruiters are of varying levels of sophistication, from established entities to informal channels of word-of-mouth recruiting, sometimes by former $\mathrm{H}-2 \mathrm{~A}$ workers themselves. ${ }^{56}$ Regardless of how they find out about the job, these new set of H-2A workers must appear at U.S. consulates or embassies for a visa interview, ${ }^{57}$ a largely formulaic process that results in the $\mathrm{H}-2 \mathrm{~A}$ worker

${ }^{51}$ See id. $\$ \$ 655.161-655.165$.

52 See 8 C.F.R. $\S 214.2(\mathrm{~h})(\mathrm{ii})(\mathrm{E})(5)(\mathrm{i})(\mathrm{A})$.

53 See id. $\S 214.2(\mathrm{~h})(\mathrm{ii})(\mathrm{E})(5)(\mathrm{v})$. These "qualifications" generally relate to any employment, education, or job training requirements specified by the job order, as well as being able to perform certain job duties stated therein. See id.

${ }^{54}$ Petitioning employers must list the names of any workers who are currently in the United States, but need not do so for workers outside of the United States at the time of the filing; instead, employers are merely required to list the total number of workers for whom they are petitioning on Form I-129. See id. $\S 214.2(\mathrm{~h})(\mathrm{ii})(\mathrm{E})(2)(\mathrm{H})(3)(\mathrm{iii})(\mathrm{iii})$; see also id. $\S 214.2$ (h)(ii)(E)(5)(i)(B) ("The total number of beneficiaries of a petition or series of petitions based on the same temporary labor certification may not exceed the number of workers indicated on that document. A single petition can include more than one beneficiary if the total number does not exceed the number of positions indicated on the relating temporary labor certification.”).

${ }^{55}$ Based on documents I have received from clients and from opposing parties during litigation, in my experience, it is relatively common practice for preparers of this form to fill it out simply in the name of a certain number of "unnamed workers." $C f$. Hall, supra note 10, at 522 (citing to regulation then in effect and stating that "employers obtain permission from the U.S. Department of Labor to employ a specified number of 'unnamed aliens."').

56 See ClOSE TO SLAVERY, supra note 10, at 9 ("U.S. employers almost universally rely on private individuals or agencies to find and recruit guestworkers in their home countries, mostly in Mexico and Central America.'); No WAY TO TREAT A GUEST, supra note 19, at 22 ("[N] early all H-2A employers rely on private recruiters to find available workers in their home countries and arrange their visas and transportation to the fields."). For a recent and in-depth overview of the guestworker recruitment system, including the structural factors that lead to high degree of worker exploitation in this process, see Jennifer Gordon, Regulating the Human Supply Chain, 102 IowA L. REV. 445, 454-64 (2017).

${ }^{57}$ U.S. Citizenship AND IMMigRation SERVs., DeP’'T OF HOMELAND SECURITY, $H$ - $2 A$ 
being granted a visa, to be placed in his passport, bearing the name of the employer for whom he has been approved to work. ${ }^{58}$ Though this step is one in which it appears workers are active participants - they are the ones to formally apply for the visa in their home country and they are the ones being interviewed - in reality, the employers (and, more accurately, recruiters) continue to control the situation: recruiters often complete paperwork for the workers and coach workers on what to say in their visa interviews. ${ }^{59}$

Despite these numerous requirements, including the involvement of several government agencies at various steps, employers easily evade compliance with the regulations governing worker recruitment. By way of example, a recent investigative article detailed the degree to which employers affirmatively skirt the positive recruitment process, placing incomplete advertisements in newspapers or advertising in locations unlikely to generate any applicants, dissuading applicants by making the job sound as undesirable as possible or including productivity requirements that no worker is likely to meet, and lying to applicants by telling them there are no longer any job openings. ${ }^{60}$ Employers have also been found to blatantly discriminate against current or past U.S. workers, systematically firing them in order to bring in more H-2A workers, all the while asserting that there are no available U.S. workers to meet the employer's labor needs. ${ }^{61}$ On a broader level, others have

Temporary Agricultural Workers, https://www.uscis.gov/working-united-states/temporaryworkers/h-2a-temporary-agricultural-workers (last visited July 6, 2017) ("Step 3: Prospective workers outside the United States apply for a visa and/or admission. . . Apply for an H-2A visa with the U.S. Department of State (DOS) at a U.S. Embassy or Consulate abroad and then seek admission to the United States. . .")

${ }^{58}$ See Alana Semuels, For U.S. farmers and Mexican workers, it's tough being legal, L.A. TIMES, Mar. 30, 2013, http://www.latimes.com/nation/la-na-guest-worker-20130331dto-htmlstory.html (including image of two H-2A workers' visas with "The North Carolina Growers Association" written on them).

59 See, e.g., ClOSE TO SlAVERY, supra note 10, at 13 ("[T]wo consulates in Latin America routinely asked prospective $\mathrm{H}-2$ workers how much they had paid in recruitment fees, apparently out of concern that a high level of indebtedness would cause workers to overstay their visas in order to repay the debt. Workers were told by their recruiters what the 'correct' - that is, false - answer should be, and workers dutifully understated the fees that they had paid.")

${ }^{60}$ See, e.g., Jessica Garrison et al., “All You Americans are Fired,” BuZZFEED, Dec. 1, 2015, $\quad$ https://www.buzzfeed.com/jessicagarrison/all-you-americans-arefired?utm term=.ix5ebqggK\#.vrLZmlKK3 [hereinafter "All You Americans Are Fired”]. In the piece, the Buzzfeed reporters tell the story of Linda White, a Louisiana-based agent who helped employers file $\mathrm{H}-2$ applications with the government who had recently been sentenced to federal prison for falsifying receipts for newspaper ads. In an interview with the reporters, she explained: "nobody was going to call for these jobs over dumb newspaper ads anyhow. When clients come to me, what they want is their Mexicans."

61 See Close TO SLAVERY, supra note 10, at 31 (summarizing complaint filed by the Equal Employment Opportunity Commission against Georgia-based Hamilton Growers, Inc., alleging discrimination against over 600 U.S. workers, by systematically firing workers 
critiqued the $\mathrm{H}-2 \mathrm{~A}$ recruitment process as a self-perpetuating cycle that provides employers with a "highly productive and compliant workforce," to which employers become accustomed and for which they thus develop a preference, thereby shutting out U.S. workers entirely. ${ }^{62}$

Employers and their representatives often criticize the H-2A program

as being overly complicated and involving high levels of red tape. ${ }^{63}$ Despite these complaints, it is easy enough to appear rule-abiding on paper. The purportedly burdensome regulations are not enough to dissuade employers from turning to the $\mathrm{H}-2 \mathrm{~A}$ program and the imported labor force that comes along with it. It is no coincidence, then, that the H-2A program has grown at such dramatic rates ${ }^{64}$ in recent years, and, as the next section outlines, it should similarly be no surprise that the trends of regulatory non-compliance continue into the period when the workers are in the United States.

\section{The H-2A Program's Substantive Provisions}

Once an employer has turned to the H-2A program and successfully imported its laborers, the employer now faces a second set of regulations that govern the program - those concerning the job terms and conditions that employers must provide to $\mathrm{H}-2 \mathrm{~A}$ workers in the United States. In the following sections, I provide an overview of some of the key parts of the $\mathrm{H}$ $2 \mathrm{~A}$ regulatory scheme. In so doing, I highlight not just the rights that are afforded to the H-2A workers themselves, but also the counterintuitive reasoning behind such protections, as well as an explanation of the rampant violations of those rights. In short, while the protections afforded to workers appear to be robust, such robustness is illusory both in purpose and execution.

over a course of three years, subjecting U.S. workers to disparate terms and conditions of work as compared to the H-2A workers, and making race-based comments to the U.S. workers); see also "All You Americans Are Fired," supra note 60 (discussing Hamilton Growers case along with other anecdotes of employers intentionally attempting to avoid hiring U.S. workers); No WAY TO TREAT A GUEST, supra note 19, at 21 (listing common strategies used by employers to dissuade U.S. workers and telling the story of two experienced female agricultural workers in North Carolina who were fired for failing to meet a production standard).

${ }^{62}$ Jennifer J. Lee, U.S. Workers Need Not Apply: Challenging Low-Wage Guest Worker Programs, 28 STAN. L. \& POL'Y REV. 1, 6 (2017).

${ }^{63}$ See, e.g., Vanessa Rancano, Will Trump's Tough Talk on Immigration Cause a Farm Labor Shortage?, NAT'L PUB. RADIO, Jan. 21, 2017, http://www.npr.org/sections/thesalt/2017/01/21/510593227/will-trumps-tough-talk-on-

immigration-cause-a-labor-shortage (summarizing farmer complaints about H-2A program as being "cumbersome and expensive").

${ }^{64}$ See supra notes 26-40 and accompanying text. 
a. Substantive Protections for H-2A Workers

The substantive protections afforded to $\mathrm{H}-2 \mathrm{~A}$ workers cover a range of topics. The core of these protections concerns wages and other job-related expenses, but they also extend to secondary issues such as housing for workers and workers' compensation coverage. I briefly discuss this bundle of rights below.

First, the government sets out specific requirements for the wages that must be paid to H-2A workers. Specifically, the employer must pay the highest of "the [Adverse Effect Wage Rate], the prevailing hourly wage rate, the prevailing piece rate, the agreed-upon collective bargaining rate, or the Federal or State minimum wage rate, in effect at the time work is performed." 65 In practice, the highest of these tends to be the Adverse Effect Wage Rate, or "AEWR" as it is known. ${ }^{66}$ The AEWR is set annually on a state-by-state basis; for 2018, the AEWR varied between $\$ 10.69$ and $\$ 14.12$ per hour, depending on the state. ${ }^{67}$ Employers are permitted to pay workers on a piece rate, ${ }^{68}$ but must ensure that the effective hourly rate is at least as high as what would otherwise be required under the regulations, including supplementing a worker's earnings if they fall below such a threshold. ${ }^{69}$

In addition to a base level pay per hour, the regulations also contemplate a base level of pay for the entire contract period. This is because of a provision of the regulations known as the "three-fourths guarantee," which requires an employer to "guarantee to offer" at least three-fourths of the hours contemplated by the work contract (generally, the "work contract" is the job order submitted to U.S. DOL), beginning on the first workday after the employee arrives to the worksite, and running through the end date on the period of need specified on the contract. ${ }^{70}$ In the event the employer fails to meet this guarantee, he must supplement a worker's pay such that the total pay equals what the worker would have earned had he actually been offered

6520 C.F.R. $\S 655.122(1)$.

${ }^{66}$ See No WAY TO TREAT A GUEST, supra note 19, at 15 ("In most cases, the AEWR is the highest rate."). The method for calculating the AEWR has been criticized as resulting in an artificially low wage rate that does not meet the stated purpose of ensuring no U.S. workers are adversely affected by the set wage. See Lee, supra note 62, at 10-11; see also CLOSE TO SLAVERY, supra note 10, at 31.

${ }^{67} \mathrm{See}$ OFFICE OF FOREIGN LABOR CERTIFICATION, EMPLOYMENT \& TRAINING ADMIN., U.S. DEP'T OF LABOR,, FY 2018 Adverse Effect Wage Rates, https://www.foreignlaborcert.doleta.gov/pdf/AEWR/AEWR_Map_2018.pdf (last visited Jan. 26, 2018).

${ }^{68}$ Commonly used in agriculture, a piece rate is a pay rate based on the quantity of certain units produced, e.g. buckets, barrels, or pounds of produce picked.

${ }^{69}$ See 20 C.F.R. $\$ 655.122(1)(2)$.

${ }^{70}$ See id. $\S 655.122(\mathrm{i})(1)$. 
all such required hours. ${ }^{71}$ There are circumstances under which the guarantee would not apply, however: in the event an H-2A worker is displaced pursuant to the 50-percent rule, discussed in the following section, and there is a general "Act of God" defense that would modify the guarantee to only cover the period until performance of the work contract becomes impossible. ${ }^{72}$

Employers are also generally required to cover a worker's transportation costs. Specifically, employers are required to either advance "transportation and subsistence" costs to H-2A workers, "from the place from which the worker has come to work for the employer, whether in the U.S. or abroad to the place of employment," or must reimburse workers such costs by the $50 \%$ point of the contract. ${ }^{73}$ With respect to return costs, the employer must "provide or pay for the worker's transportation and daily subsistence from the place of employment to the place from which the worker . . . departed to work for the employer" when the worker completes the contract period or if he is terminated without cause and lacks any "immediate subsequent H-2A employment." transportation from worker housing to the jobsite. ${ }^{75}$

An employer is also required to cover all expenses related to applying for and securing H-2A workers, and is prohibited from passing on those costs to any employee. ${ }^{76}$ Specifically, employers are required to assure that they

${ }^{71}$ See id. $§ 655.122(i)(1)(i v)$ ("If during the total work contract period the employer affords the U.S. or H-2A worker less employment than required under this paragraph, the employer must pay such worker the amount the worker would have earned had the worker, in fact, worked for the guaranteed number of days.").

72 See id. $\S 655.122(0)$ ("In the event of such termination of a contract [due to impossibility], the employer must fulfill a three-fourths guarantee for the time that has elapsed from the start of the work contract to the time of its termination.").

${ }^{73} I d . \S 655.122(\mathrm{~h})(1)$. Though the regulations specify the halfway-point of the contract as being the deadline by which to reimburse workers, certain courts have interpreted the Fair Labor Standards Act ("FLSA") as imposing a requirement that they be reimbursed in the first week of work in certain circumstances, holding that pre-arrival expenses are de facto deductions that must be reimbursed in the first week to the extent they bring a worker's earnings below the minimum wage. See, e.g., Arriaga v. Fla. Pac. Farms, L.L.C., 305 F.3d 1228, 1232 (11th Cir. 2002) (FLSA requires employer to reimburse H-2A workers for "transportation, visa, and immigration expenses" in first workweek). The H-2A regulations make particular note of the fact that the FLSA may impose additional, independent requirements on employers, thus providing support for a separate theory of recover under federal law. See 20 C.F.R. $\S 655.135$ (e) ("H-2A employers may also be subject to the FLSA. The FLSA operates independently of the H-2A program and has specific requirements that address payment of wages, including deductions from wages, the payment of Federal minimum wage and payment of overtime.").

7420 C.F.R. $\$ 655.122(\mathrm{~h})(2)$.

75 See id. $\S 655.122(\mathrm{~h})(3)$.

${ }^{76}$ Interestingly, the prohibition on passing along these costs covers not simply H-2A workers, but all employees. See 20 C.F.R. $§ 655.135(\mathrm{j})$ (using the term "employee"); see also id. $\S$ 655.103(b) (separately defining "employee" and "H-2A worker"). 
and their agents have not "sought or received" payment "for any activity related to obtaining H-2A labor certification," which explicitly includes the following items: "the employer's attorneys' fees, application fees, or recruitment costs." 77 Moreover, the term "payment" is defined broadly, and covers "monetary payments, wage concessions (including deductions from wages, salary, or benefits), kickbacks, bribes, tributes, in kind payments, and free labor."78 Employers are also required to "contractually forbid[] any foreign labor contractor or recruiter (or any agent of such foreign labor contractor or recruiter) whom the employer engages, either directly or indirectly, in international recruitment of $\mathrm{H}-2 \mathrm{~A}$ workers to seek or receive payments or other compensation from prospective employees." ${ }^{, 79}$ In short, it is relatively clear: the $\mathrm{H}-2 \mathrm{~A}$ workers are not supposed to cover any costs or pay any fees related to their $\mathrm{H}-2 \mathrm{~A}$ visa.

Workers must also be provided with free housing that meets certain federal housing standards, ${ }^{80}$ and employers are required to carry workers' compensation insurance. ${ }^{81}$ While the latter requirement may not appear particularly onerous, it is a marked change in H-2A heavy states, as many states-particularly in the south-generally exempt agricultural work from their state workers' compensation system. ${ }^{82}$ As a result, this requirement in fact represents an additional protection for $\mathrm{H}-2 \mathrm{~A}$ workers, as compared to U.S. workers in such states.

\section{b. The True Intended Beneficiaries of the Substantive Protections}

The scope of the regulations outlined above may lead one to assume that $\mathrm{H}-2 \mathrm{~A}$ workers benefit from a robust set of labor protections. Indeed,

${ }^{77} I d . \S 655.135(\mathrm{j})$.

${ }^{78} I d$.

${ }^{79} \mathrm{Id} . \S 655.135(\mathrm{k})$.

${ }^{80} \mathrm{H}-2 \mathrm{~A}$ employers "must provide housing at no cost to the H-2A workers ... who are not reasonably able to return to their residence within the same day." Id. § 655.122(d)(1). The housing must meet standards set forth by either the Employment and Training Administration or the Occupational Safety and Health Administration, depending on the date the housing was constructed. See id. $\S 654.401$. Other standards may apply in the event the employer pays for rental or public accommodations to house workers. See id. $\S 655.122(\mathrm{~d})(1)(\mathrm{ii})$.

${ }^{81} \mathrm{See} 20$ C.F.R. $\S 655.122(\mathrm{e})(1)$.

82 See FARMWORKER JUSTICE, Workers' Compensation, https://www.farmworkerjustice.org/content/workers-compensation (last visited Oct. 23, 2017) (listing the following states as those that do not require the workers' compensation for farm labor in any circumstances: Alabama, Arkansas, Delaware, Georgia, Indiana, Kansas, Kentucky, Mississippi, Missouri, Nebraska, Nevada, New Mexico, North Dakota, South Carolina, Tennessee, and Texas, and noting that an additional eight states limit the circumstances under which such coverage must be provided). 
some of the rights provided to them via regulation go above and beyond what similarly situated U.S. workers are guaranteed, such as the applicable minimum wage rate and the requirement of having workers' compensation coverage. However, a closer look at the entirety of the regulatory framework - and the way some courts have treated it - reveals that U.S. workers, rather than H-2A workers, are the individuals intended to benefit from this system, further cementing H-2A workers' status as outsiders to the program.

To begin, the $\mathrm{H}-2 \mathrm{~A}$ regulations themselves make this less-preferred status clear in discrete ways. Specifically, the regulations include a provision termed the "50 percent rule," whereby an employer must provide employment to a "qualified, eligible U.S. worker who applies to the employer until 50 percent of the period of the work contract has elapsed." 83 This regulation is in keeping with the H-2A program's stated purpose of employing U.S. workers to the extent possible, and thus should not be a total surprise. However, its execution would likely be at significant cost to a displaced $\mathrm{H}-2 \mathrm{~A}$ worker ${ }^{84}$ because he would lose substantive rights he would otherwise be afforded. Such a worker would no longer receive the protection of the three-fourths guarantee, ${ }^{85}$ and, while the regulations would require his employer to cover his return transportation, ${ }^{86}$ it is not clear that they obligate the employer to reimburse any inbound travel and subsistence costs. ${ }^{87}$ More fundamentally, the relatively high-paying job in the U.S. agricultural sector ${ }^{88}$ that the worker anticipated completing in full would now be cut short, depriving him of the ability to earn wages for the entirety of the season.

On a broader scale, this preference has also emerged in specific efforts

${ }^{83}$ Id. $\S 655.135(\mathrm{~d})$.

${ }^{84}$ Given the dramatic increase in the use of the H-2A program and employers' efforts to turn away U.S. workers, see supra notes 60-61, displaced H-2A workers are probably few and far between. Regardless, the way in which the regulations would operate in this situation are clear, as is discussed in the text.

${ }^{85}$ See supra notes 70-72 and accompanying text.

${ }^{86}$ See 20 C.F.R. $\S 655.122(\mathrm{~h})(2)$ ("The employer is not relieved of its obligation to provide or pay for return transportation and subsistence if an $\mathrm{H}-2 \mathrm{~A}$ worker is displaced as a result of the employer's compliance with the 50 percent rule . . . with respect to the referrals made after the employer's date of need.").

87 Unlike the outbound transportation regulation, see supra note 74 , the inbound transportation regulation contains no provision about what would occur in the event an $\mathrm{H}-$ 2A worker were to be displaced by a U.S. worker, see 20 C.F.R. $\S 655.122(\mathrm{~h})(1)$. It is arguably not even triggered, as the regulation itself in theory only obligates the employer to reimburse once the halfway-point of the contract is reached, and any situation with possible displacement of H-2A workers would occur before that halfway point, per the very nature of the 50 percent rule itself. Of course, there may be freestanding obligations under the FLSA, as discussed above, see supra note 73.

${ }^{88}$ See infra note 126. 
to enforce H-2A workers' rights. This battle played out when advocates attempted to file lawsuits in federal court on behalf of $\mathrm{H}-2 \mathrm{~A}$ workers, asserting "an implied right of action to enforce those provisions of federal law which establish the $\mathrm{H}-2 \mathrm{~A}$ program and impose its minimal conditions of employment." 89 Courts disagreed, based in part "on the rationale that the $\mathrm{H}$ $2 \mathrm{~A}$ statute and regulations were not intended to especially benefit alien workers . . . [but,] rather, their stated purpose is to protect the jobs of United States citizens." 90 Thus, the H-2A regulations, on their own, do not provide any free-standing enforceable rights for those workers. ${ }^{91}$ As one observer has commented, "the protection afforded to H-2A workers by these rights was incidental, rather than intentional." 92

In sum, though the $\mathrm{H}-2 \mathrm{~A}$ program is characterized by a relatively robust regulatory scheme, this framework does not exist for the benefit of $\mathrm{H}$ 2A workers. Indeed, the flaws are inherent to the system: the H-2A program is "intended to achieve the dual and potentially conflicting goals of meeting employers' temporary labor needs while protecting the interests of U.S. workers." 93 Guaranteeing the labor and employment rights of the H-2A workers actually filling these jobs is omitted entirely from this set of priorities, perhaps unsurprisingly, given their outsider status. In the following section, I show how the failure to protect $\mathrm{H}-2 \mathrm{~A}$ workers also extends to the operation of the regulatory scheme in practice.

c. The Utter Failure of the Substantive Protections

Despite the breadth of the regulatory framework, mistreatment of $\mathrm{H}$ -

${ }^{89}$ Holley, supra note 19, at 606.

${ }^{90}$ Id. (quoting Nieto-Santos v. Fletcher Farms, 743 F.2d 638, 641 (9th Cir. 1984)) (alteration in original).

${ }^{91}$ As I explain below, see infra section $\operatorname{II}(B)(2)(c)$, this does not mean there is no legal remedy; the mechanism for enforcing such rights is a state law breach of contract claim, but such an approach has the significant downside of leaving workers with the option of filing in a likely unfavorable state forum, absent any other federal claim.

92 Id. at 607.

${ }^{93}$ Smith, supra note 19 , at 382 . While the goals are conflicting, it is worth noting that advocates filing claims on behalf of $\mathrm{H}-2 \mathrm{~A}$ worker clients may seek to generate more favor among judicial and even general audiences by emphasizing the U.S. worker goal in particular. Specifically, they may paint the employer as law-evading for not just failing the H-2A workers, but also for failing the U.S. workers the employer is theoretically supposed to seek to employ as an initial matter. See Jennifer J. Lee, Outsiders Looking in: Advancing the Immigrant Worker Movement Through Strategic Mainstreaming, 2014 UTAH L. REV. 1063, 1076 (2015) ("Litigants may be more successful if they advocate policy justifications that consider the impact on workers generally, rather than just on the litigants before the court. Courts, for example, rationalize that denying wage and hour protections for immigrant workers has the perverse result of harming citizen workers by encouraging employers to engage in illegal hiring of undocumented workers, contrary to IRCA."). 
2A workers is widespread. Stated otherwise, for each protection outlined above, there is abundant evidence of non-compliance among $\mathrm{H}-2 \mathrm{~A}$ employers. I briefly highlight some of these issues below. ${ }^{94}$

First, underpayment of $\mathrm{H}-2 \mathrm{~A}$ workers is rampant. This is due to several factors. One factor is the use of piece rate pay. Employers generally prefer to pay by the piece because it is believed to "encourage[] workers to work faster than they would under an hourly rate and produce more for the employer." 95 While piece rate pay is permissible, given to ensure compliance with the applicable minimum hourly rate, ${ }^{96}$ sometimes workers are forced to turn over their supplemental pay to a crew leader or supervisor as a kickback. ${ }^{97}$ More often, employers fail to supplement the piece rate at all and simply cover their tracks: employers do not record the actual hours worked by the H-2A workers, and instead back into the "hours worked" by dividing the total actual pay by the mandated hourly wage, and documenting the result as the number of hours that were supposedly worked. ${ }^{98}$ By doing so, employers seek to insulate themselves against any possible complaints of underpayment, including enforcement through U.S. DOL investigations or private litigation.

Workers also experience wage theft in other ways. Employers often unlawfully deduct from workers' wages for items that the employer is legally supposed to provide, such as work tools or transportation costs, ${ }^{99}$ the latter of which is a foreseeable expense for every $\mathrm{H}-2 \mathrm{~A}$ job, given that $\mathrm{H}-2 \mathrm{~A}$ workers necessarily must migrate to and from their homes in other countries. These violations are common when it concerns transportation costs: in one study, based on interviews of several hundred Mexican H-2A workers, $62 \%$ of the workers reported having to pay some or all of their own transportation expenses. ${ }^{100}$ Moreover, many H-2A workers are charged unlawful "visa" or

\footnotetext{
${ }^{94}$ For more a more in-depth discussion of the abuses in the H-2A program, see Smith, supra note 19, at 385-93 (detailing the abuses of the H-2A and H-2B guestworker programs as well as the root causes); CLOSE TO SLAVERY, supra note 10, at 9-41 (in depth discussion of abuses in both H-2A and H-2B guestworker programs); NO WAY TO TREAT A GUEST, supra note 19, at 21-31 (discussing $\mathrm{H}-2 \mathrm{~A}$ program specifically).

95 No WAY TO TREAT A GuEST, supra note 19, at 24.

${ }^{96}$ See supra note 69 and accompanying text.

${ }^{97}$ See No WAY TO TREAT A GUEST, supra note 19, at 24.

98 See id. at 24; see also ClOSE TO SLAVERY, supra note 10, at 18 (noting "underreporting of hours" as a form of wage theft").

${ }^{99}$ See ClOSE TO SLAVERY, supra note 10, at 18 ("According to the law, employers must cover the costs of items that principally benefit the employer, such as work tools, safety equipment, and - in most parts of the country - workers' travel and visa expenses to come to the United States. Yet, employers routinely fail to reimburse workers for their travel and visa expenses, and they frequently make deductions from workers' paychecks for items that are for the benefit of the employer.").

${ }^{100}$ See Jornaleros SAFE, MEXICAN H-2A FARMWORKERS IN THE UnITED STATES: THE
} 
recruitment fees. Such fees are typically charged by recruiters before workers depart for the United States; knowing that the supply of would-be H-2A workers exceeds the demand, "recruiters have a significant incentive to charge recruiting fees at great personal profit." 101 Workers' acceptance of this situation is not entirely irrational: as one scholar has noted, "[d]espite the high costs, guestworkers come to the U.S. because they believe they will make sufficient money to cover any expenses and still earn money for themselves and their families." 102 To further compound the problem, many workers take out loans to pay for travel or other job-related expenses in their home country, and these unlawful charges simply put them deeper into debt. ${ }^{103} \mathrm{H}-2 \mathrm{~A}$ workers are thus left in a financially precarious position, rendering them particularly vulnerable to mistreatment and abuse.

Non-compliance is also common outside of the core financial protections. Workers are often provided with substandard and dangerous housing. ${ }^{104}$ One report has criticized this situation as being the result of "a tangled mass of state and federal regulations and agencies [that] holds authority over farmworker housing," making it possible that "deplorable [housing] conditions may go unnoticed." 105 With respect to workers' compensation, even if a worker receives medical treatment while in the United States, it can be nearly impossible for injured workers to access benefits once they have returned home. ${ }^{106}$ And this all falls against the backdrop of one of the most dangerous industries in which to labor, the agricultural industry. ${ }^{107}$

In short, for almost every regulation that is meant to protect $\mathrm{H}-2 \mathrm{~A}$ workers, one is just as likely to find widespread employer evasion and

INVISIBLE WORKFORCE 11 (2013), available at https://static1.squarespace.com/static/57d09e5c5016e1b4f21c9bd3/t/58c32e7cebbd1a93b1 805532/1489186429991/EXECUTIVE+SUMMARY+Jornaleros+SAFE.pdf.

${ }^{101}$ No WAY TO TREAT A GUEST, supra note 19, at 23; see also Smith, supra note 19, at 378 (noting that employers "can select from a nearly limitless supply of temporary foreign employees").

102 Smith, supra note 19, at 386.

${ }^{103}$ See, e.g., Smith, supra note 19, at 386 (despite prohibition on charging H-2A workers recruitment fees and for costs associated with obtaining labor certification, employers and recruiters nevertheless "sometimes charge unlawful fees and put guestworkers further into debt"); see also NO WAY TO TREAT A GUEST, supra note 19, at 23 (noting that some workers leave deeds to homes or cars as collateral for loans in sending countries); CLOSE TO SLAVERY, supra note 10, at 9 (same).

${ }^{104}$ See Close to SlaVery, supra note 10, at 35; No WAY TO TREAT A GUEST, supra note 19 , at 28-29.

${ }^{105}$ No WAY TO TREAT A GUEST, supra note 19, at 29.

106 See ClOSE TO SLAVERY, supra note 10, at 25-26; No WAY TO TREAT A GUEST, supra note 19 , at $27-28$.

107 See Close to Slavery, supra note 10, at 25; No WAY TO TREAT A GUEST, supra note 19 , at $27-28$. 
mistreatment of workers. But in reality, the harms extend even further. As one scholar has observed, many of the abuses experienced by H-2A workers do not give rise to legally actionable claims, simply because the regulatory framework does not address common abusive practices such as intimidating or threatening workers. ${ }^{108}$ Moreover, for certain types of violations-for example, substandard housing-the remedy lies exclusively or more naturally with the government, as private litigants cannot enforce housing codes, and it would be difficult to compute damages for such legal violations. These obvious gaps reinforce the outsider status of H-2A workers: workers whose rights are arguably protected, though not with any intent to benefit them, and with little hope those protections will be met and with further hurdles to obtain any legal recourse. In the following section, I turn to a more in-depth discussion of this final point: the numerous and substantial barriers to achieving remedies for violations of $\mathrm{H}-2 \mathrm{~A}$ workers' rights.

\section{B. Limited Rights and Complicated Remedies}

With the above background on the $\mathrm{H}-2 \mathrm{~A}$ program and its inherent flaws in mind, I now turn to the second part of the broader problem regarding the abuses experienced by H-2A workers: the complications and barriers that operate, both practically and legally, to limit the available methods to redress those wrongs. In general, these factors can be divided into two categories. On the one side are complicating factors that exist within the client community itself - in other words, characteristics that are generally true of H-2A workers and their situation of being in this country on temporary visas for the purposes of doing agricultural work. On the other are the barriers that are inherent to the legal and enforcement structures that are available to $\mathrm{H}-2 \mathrm{~A}$ workers. I discuss each of these sets of factors in turn below.

\section{Complications with the Client Base}

In looking at the complications that arise because of the situation of $\mathrm{H}-2 \mathrm{~A}$ workers in particular, there are three general points to consider: cultural and linguistic barriers, the temporary and isolated nature of workers' presence in this country, and the high risk of retaliation that they face. In many ways, these factors are also true of other marginalized communities in the United States, particularly communities of immigrant and/or undocumented workers. However, it is the ways in which these three barriers

${ }^{108}$ See Lee, supra note 62, at 17-18 ('Even an employer's more egregious acts, such as intimidating workers, denying medical care, or threatening workers, generally cannot be reached under the [U.S. DOL] complaint process because there are no specific regulatory provisions that address these issues."). 
interact and build upon another, resulting in a particularly unique vulnerability to a sweeping type of retaliation, that makes the situation that much more severe for $\mathrm{H}-2 \mathrm{~A}$ workers as a distinct group.

\section{a. Cultural and Linguistic Barriers}

The first barrier that exists among the client base is the cultural and linguistic setting in which $\mathrm{H}-2 \mathrm{~A}$ workers operate. H-2A workers tend to be monolingual Spanish speakers, with some speaking Spanish as a second language or only speaking an indigenous language. ${ }^{109}$ Moreover, they grew up and still reside in other countries, and often come from lower-income or impoverished communities in their sending countries. ${ }^{110}$

As a result, the U.S. legal system - both the laws and the mechanisms used to enforce them - is not something with which H-2A workers tend to be readily familiar. To be fair, the U.S. legal system can seem quite foreign to marginalized communities in the United States. ${ }^{111}$ However, there is at least

${ }^{109}$ See, e.g., Smith, supra note 19, at 390 (noting the linguistic isolation experienced by guestworkers who may not speak English or who "speak only languages, such as Mixteco Bajo, which have no written component and are not commonly spoken in the U.S."); Holley, supra note 19, at 613 (characterizing H-2A workers as "Spanish-speaking"); CLOSE TO SLAVERY, supra note 10, at 28 (stating that H-2 workers "usually speak no English"), 10-11 (noting that many Guatemalan workers are illiterate and speak Spanish as a second language).

110 One report from 2013 summarized the situation for $\mathrm{H}-2 \mathrm{~A}$ workers as follows: The simple fact is that workers from Mexico, Guatemala and many other countries often have very few economic opportunities. In recent years, rural Mexicans have had an increasingly difficult time making a living at subsistence farming, and in some regions there are virtually no wagepaying jobs. Where jobs exist, the pay is extremely low; unskilled laborers can earn 10 times as much, or more, in the United States as they can at home. Most perceive the guestworker program as their best chance to get to the United States and provide a better life for their families.

ClOSE TO SLAVERY, supra note 10, at 12.

111 The sense of foreignness can be quite literal. Lucie White has written about the "culture clash" that can occur when a poor person enters a courtroom, noting that "[p]oor people obviously do not speak in the same dialect that lawyers, judges, and elite businesspeople use." Lucie E. White, Mobilization on the Margins of the Lawsuit: Making Space for Clients to Speak, 16 N.Y.U. REV. L. \& Soc. CHANGE 535, 543 (1987-1988). To that end, she has equated a lawyer's job with serving as "a translator," "shap[ing] her client's experiences into claims, arguments, and remedies that both the client and the judge can understand." Id. at 544; see also Jacobs, supra note 17, at 373 (lawyer has to "translate" client's story and "assist the listener[s]" within the legal system "to understand client's story); Miller, supra note 15, at 516-17 ("The lawyer translates the client's story so it can be heard and understood in the legal system.”). In a different context, Kathryn Sabbeth has made a similar observation about the gap that lawyers can fill when representing indigent clients, writing that, "without access to lawyers with time for adequate representation, many indigent 
a certain degree of osmosis, not to mention outright civic education, ${ }^{112}$ with individuals who have grown up in this culture and who speak the same literal (though perhaps not figurative ${ }^{113}$ ) language of the participants and deciders in its legal system.

By contrast, H-2A workers may arrive to the United States with expectations based on their understanding of how the legal system functions back home. One observer has commented on this phenomenon in the context of another subset of low-wage immigrant workers, those laboring in the poultry industry:

Peripheral poultry workers may carry over legal knowledge from their home countries, which may have less robust, or even less robustly enforced, labor and employment rights regimes. They may have experience with corruption in the justice system of their home countries. Undocumented workers in particular may have a deep mistrust of the U.S. government, believing that interaction even with "friendly" or "status-neutral" agencies puts the worker at risk of deportation." 114

In short, the substantive protections, the remedies, even the role of lawyersall of this varies from country to country and culture to culture, and those bridges can be difficult to cross in the context of H-2A workers.

Admittedly, the same may be true of immigrant worker communities who have settled in the United States, particularly recently. The above-cited poultry industry study makes that clear. However, H-2A workers' cultural and linguistic context does not operate on its own, but is instead just one of the several factors that combine to make the remedies difficult to achieve with the client base. Next, I turn to the second such factor-the limited and

litigants, both civil and criminal, find their experience in the adversary process quite disrespectful of their basic dignity." Kathryn A. Sabbeth, Towards an Understanding of Litigation as Expression: Lessons from Guantánamo, 44 U.C. DAVIS L. REV. 1487 (2011).

112 Thank you to Deborah Archer for this insight regarding the educational system's role in teaching about the judicial branch of government in the United States.

113 See supra note 111.

${ }^{114}$ Charlotte S. Alexander, Explaining Peripheral Labor: A Poultry Industry Case Study, 33 BERKELEY J. EMP. \& LAB. L. 353, 382 (2012); see also Manoj Dias-Abey, Justice on our fields: Can “alt-labor" organizations improve migrant farm workers' conditions?, 53:1 HARV. C.R.-C.L. L. REV. (forthcoming 2017) (manuscript at 9) ("In the case of migrant farm workers, their interactions with the law in their home countries (e.g. negative experiences with state officials) may affect their readiness to make use of formal law to resolve workplace issues."); Charlotte S. Alexander \& Arthi Prasad, Bottom-Up Workplace Law Enforcement, 89 IND. L. J. 1069, 1101 (2014) ("Immigrant workers may also import legal knowledge from their home countries that is inapplicable in their U.S. workplaces and derive inaccurate beliefs about their workplace rights from relatively insular information 'islands' and ethnic networks."). 
isolated nature of H-2A workers' presence in this country.

\section{b. Limited and Isolated Physical Presence in United States}

H-2A workers' presence and, therefore, their availability to directly engage with legal systems in the United States is marked by two significant complications. By their very nature, $\mathrm{H}-2 \mathrm{~A}$ workers are only present in the United States temporarily, and, because they are here to perform agricultural labor, they tend to live in rural settings, usually in employer-provided housing on employer property. ${ }^{115}$ Moreover, H-2A workers generally work long hours, with limited free time; they take the jobs in the first place so that they can earn as much as possible to support their family back home. Even if a worker returns to the same employer year after year, thus establishing some degree of consistency in his presence over time, these same limitations are present: such a worker is generally only in the United States for the purposes of working, residing full-time on employer property with few opportunities to leave, and is thus not integrated into the local community - at least not in the same way that would be true of settled immigrant worker communities.

What does this isolation mean for accessing the U.S. legal system in the event $\mathrm{H}-2 \mathrm{~A}$ workers experience violations of their rights? As a starting point, they are much less likely to encounter actors who would help them engage with the legal system. Legal services offices and other advocacy groups often conduct worker outreach to inform workers about their rights and the services that their organizations offer. However, both of aspects of H-2A workers' physical presence in the United States mentioned above- the temporariness of that presence and the isolated nature of that presence-make the task of establishing connections between legal advocates and workers much more difficult. H-2A workers can be hard to locate in rural settings ${ }^{116}$

115 For a discussion of the ways in which this physical isolation of living in employercontrolled housing interrelates with and contributes to other forms of isolation, leaving workers even more vulnerable, see Smith, supra note 19, at 388-91.

116 Though H-2A employers must disclose the location of worker housing on the job order they file with the U.S. government, see ETA Form 790, supra note 44 (box 3), which is made publicly available through the public job registry, see U.S. DEP'T OF LABOR, iCERT Portal, https://icert.doleta.gov/ (last visited Aug. 1, 2017), it is not uncommon for the housing information to be incorrect, overly broad, or even misleading, rendering the job of outreach workers seeking to meet with $\mathrm{H}-2 \mathrm{~A}$ workers all the more difficult, if not impossible. Moreover, the job order similarly requires disclosure of the anticipated period of employment, see ETA Form 790, supra note 44 (box 9), but workers often arrive after the given start date, due to delays on either end, such as crop readiness issues or complications encountered during worker migration into the United States. Such uncertainty further complicates outreach, because outreach workers may plan to visit a farm just after the anticipated start date, particularly if the season is short, expecting workers to have arrived, when they may not actually be at the farm yet. 
and it can be time-consuming to conduct outreach to significant numbers of workers. ${ }^{117}$ To complicate things even further, outreach workers often search for H-2A workers at their residences; because these are on employer property, employers may encounter the outreach workers and, finding their message about worker rights to be undesirable, kick them out, often under threat of calling law enforcement. ${ }^{118}$ In short, the very ability to reach workers directly is limited, and so it is likely that the vast number of workers go without direct contact with advocates. This is all compounded by the legal knowledge gap that may exist, as documented above ${ }^{119}$ — even if an outreach worker does get the chance to talk to H-2A workers, it can be difficult to quickly convey a comprehensible and accessible message to workers about their legal rights and options for recourse in the United States.

By contrast, most recent immigrant worker advocacy efforts have tended to take place in urban settings. ${ }^{120}$ The benefits of this are obviousthe density of community members, the intersecting potential networks, and relative ease of access and its effect on organizing events, to name just a few-and the contrast of the H-2A worker setting could not be more stark. Workers are hard to reach, rendering messages difficult to convey and thus legal engagement much more challenging. This situation is further complicated by an overarching and deeply ingrained problem-the risk of retaliation and the effect that has on worker attitudes. I turn to this next.

117 The number of H-2A workers at any given farm can vary substantially depending on the region and the industry. For example, the tobacco industry in Kentucky tends to employ fewer H-2A workers per farm-less than a dozen workers is not uncommon, with some even significantly less than that - than, for example, the large multi-crop farms in Georgia or the citrus industry in Florida, which can have hundreds of workers per farm. Outreach in the former circumstance thus requires more time and effort to reach the same number of workers than the latter.

118 See Letter from Legal Aid Bureau, Inc., Statewide Advocacy Support Unit, Human Rights Project, to Magdalena Sepulveda Carmona, U.N. Special Rapporteur on Extreme Poverty and Human Rights, Office of the High Commissioner for Human Rights (Dec. 13, 2012), available at http://www.mdlab.org/human-rights-docs/Migrant-Farmworker-CampAccess-Human-Rights-Complaint-Dec-13-2012.pdf (documenting widespread migrant camp access issues experienced by U.S. legal services, healthcare, and community service organizations).

119 See supra section $\mathrm{II}(\mathrm{B})(2)(\mathrm{a})$.

120 See Jennifer Gordon, The Lawyer Is Not the Protagonist: Community Campaigns, Law, and Social Change, 95 CAL. L. REV. 2133, 2143 n.41 (2007) (“. . . all of these stories take place in large cities that offer non-profit organizations many potential forms of legal support, including well-developed pro bono programs in the private bar, numerous law school clinics, and both publicly- and privately-funded legal services organizations. Organizations in rural areas or smaller cities are likely to have a much more constrained set of options for representation."). 
c. Uniquely Vulnerable to Retaliation

Retaliation is not a unique problem in and of itself. Most low-wage and undocumented workers, themselves frequently exploited ${ }^{121}$ and also legal outsiders in many ways, ${ }^{122}$ face very real consequences if they speak up about workplace problems. Undocumented workers are especially vulnerable and face serious risks both at and beyond the job because of their lack of legal status. ${ }^{123}$ However, H-2A workers (and other guestworkers) are put in a particularly precarious position, and this is because of the very nature of the $\mathrm{H}-2 \mathrm{~A}$ program itself. The $\mathrm{H}-2 \mathrm{~A}$ program lacks visa portability, meaning that H-2A workers may only legally work for the employer who petitioned the U.S. government for their labor. ${ }^{124}$ It is this fundamental characteristic that gives rise to many of the problems that permeate the $\mathrm{H}-2 \mathrm{~A}$ program.

As a result, an employer has enormous power over the worker: an $\mathrm{H}$ 2A worker is not realistically given the choice of going to work somewhere else instead if he doesn't like his current job. ${ }^{125}$ Instead, the choice is more

${ }^{121}$ See, e.g., Sameer M. Ashar, Public Interest Lawyers and Resistance Movements, 95 CAL. L. REV. 1879, 1882 (2007) ("[M]ost undocumented workers operate in everyday sweatshop conditions, including consistent underpayment of wages for regular hours and overtime, health and safety violations, and hierarchical relationships of power in the workplace marked by low-intensity verbal abuse, and racial and sexual harassment.").

${ }^{122}$ See, e.g., Jennifer Gordon, We Make the Road by Walking: Immigrant Workers, the Workplace Project, and the Struggle for Social Change, 30 HARV. C.R.-C.L. L. REV. 407, 418-27 (1995) (detailing structural limitations on protection of undocumented workers' rights by government enforcement, legal services offices, and labor unions).

${ }^{123}$ See, e.g., David Weil \& Amanda Pyles, Why Complain? Complaints, Compliance, and the Problem of Enforcement in the U.S. Workplace, 27 COMP. LAB. L. \& POL'Y J. 59, 83 n.1962 (2005) ("For undocumented workers, the costs of retaliation may also relate to a threat of exposure and deportation because of immigration status."); see also Alexander, supra note 114, at 379 (noting a "constant specter of removal or deportation" for undocumented workers in the poultry industry).

${ }^{124}$ See, e.g., Smith, supra note 19, at 387 (“Guestworkers' immigration statuses are tied to their employers. . . The visas are not portable; a guestworker's visa is linked to their employer and, if their job ends, the guestworker loses their immigration status and ability to remain and work in the U.S."); Hall, supra note 7, at 528-29 (explaining the ways in which "H-2A workers are not free," including the fact that workers "cannot change employers," a problem that is "written into the system"); Holley, supra note 19, at 595 ("Unlike any other farmworker in the United States, an H-2A worker is tied to a single employer."). The regulations do contemplate that an $\mathrm{H}-2 \mathrm{~A}$ worker can change employers if the prospective employer files a new petition on behalf of the worker, see 8 C.F.R. $\S 214.2(\mathrm{~h})(\mathrm{ii})(\mathrm{E})(2)(\mathrm{D})$, however, this process is rarely used, especially among employers of Mexican nationals. See Smith, supra note 19, at 387 n.70 ("While it is theoretically possible for H-2A and H-2B guestworkers to change employers under some limited circumstances, it is quite difficult in practice.").

${ }^{125}$ In this way, the three common options faced by a worker who encounters problems at the workplace — exit, voice, and loyalty — are modified in the circumstances of an H-2A 
often between staying put in the job he now has, regardless of how bad the conditions are, or going back home, where his earnings are likely significantly lower than even unlawfully low earnings in the United States. ${ }^{126}$ What's more, this so-called choice might be taken away at moment's notice: because the employer holds the "deportation card," as some have called it, "[a]t any moment, the employer can fire the worker, call the government and declare the worker to be "illegal.","127

The consequences of retaliation are not limited to this initial moment, where a worker risks his job and legal status in the United States. Rather, they are ongoing and can be widespread. An employer can singlehandedly blacklist a complaining worker by failing to offer a visa for the same job in a subsequent season. ${ }^{128}$ In the past, employers have done so on a large scale: the North Carolina Growers Association infamously maintained a blacklist of over 1,000 workers, euphemistically entitled the "Ineligible for Rehire Report." "problem" worker - the entire community in the worker's sending country may similarly be barred from coming in on a visa in the future. ${ }^{130}$ Because recruitment streams are limited, ${ }^{131}$ the consequence of being shut out of one

worker. Thus "exit" is not just "the option to take one's labor elsewhere," but more likely than not is the option of leaving for good, potentially having nowhere else to go. See Alexander \& Prasad, supra note 114, at 1075 (discussing "exit, voice, and loyalty" theories).

126 See Alexander, supra note 114, at 377 (noting that, though immigrant workers generally are aware of their poor working conditions, "the options and opportunities at home are often significantly worse," with "the average minimum age for non-professional occupations in Mexico [being] the equivalent of roughly $\$ 4.68$ per day" and "the minimum wage in Guatemala [being] the equivalent of roughly $\$ 8.75$ per day").

127 ClOSE TO SLAVERY, supra note 10, at 14.

128 See, e.g., NO WAY TO TREAT A GUEST, supra note 19, at 31 ("Because foreign citizens have no ability to apply independently for an H-2A visa, they must hope that an employer will request a visa for them. Employers have been able to retaliate against H-2A workers who assert themselves simply by refusing to offer visas to the workers in a following season.").

${ }^{129}$ See Close to Slavery, supra note 10, at 16; see also Jennifer J. Lee, Private Civil Remedies: A Viable Tool for Guest Worker Empowerment, 46 LoY. L.A. L. REV. 31, 43 (2012) ("The North Carolina Growers' Association, for example, maintained a blacklist of H-2A workers who were barred from rehire for the following season because they had complained about job conditions, such as the inability to access drinking water in the fields."); Hall, supra note 7, at 533 (explaining that a single grower of the nearly 1,000 members of the Association could add a worker to the blacklist, thereby foreclosing any employment opportunities with all of the members in future years).

${ }^{130}$ See Smith, supra note 19, at 393 ("Blacklisting in particular is a threat sometimes turned on a guestworker's entire community if they complain or seek to improve their working conditions.").

${ }^{131}$ In other words, sending communities often have ties to a single employer in the United States or a very particular industry, meaning that workers in sending countries seeking to migrate to the United States have very limited (if any) chances for obtaining an 
job in the United States realistically means that the worker, and even other members of his home community, can lose the chance of getting an $\mathrm{H}-2 \mathrm{~A}$ visa in the future.

Though there are mechanisms by which an $\mathrm{H}-2 \mathrm{~A}$ worker can be protected if he does speak up, both related to his immigration status and to protecting him in any related litigation, ${ }^{132}$ the risk of retaliation ${ }^{133}$ is often too great a hurdle to overcome. Instead of voicing a complaint about working conditions, workers often just leave. ${ }^{134}$ By doing so, the worker does remove himself from the exploitative situation, but this is still a generally protective rather than an assertive choice, as he is likely attempting to avoid being blacklisted from other H-2A jobs. As one longtime advocate has noted: "The only time $\mathrm{H}-2 \mathrm{~A}$ workers freely express their feelings about their experiences is when they are no longer H-2A workers and have no need to be." 135

In short, while retaliation is a risk faced by nearly all low-wage or undocumented workers, the risk is particularly acute in the context of $\mathrm{H}-2 \mathrm{~A}$ workers. Despite the risks they face, undocumented workers are better situated than H-2A workers in this regard, with the key difference being their ability to change jobs. ${ }^{136}$ And undocumented workers themselves realize this

H-2A visa. See, e.g., Jessica Garrison et al., The New American Slavery: Invited to the U.S., Foreign Workers Find a Nightmare, BuZZFEED, July 24, 2015, https://www.buzzfeed.com/jessicagarrison/the-new-american-slavery-invited-to-the-usforeign-workers-f?utm term=.svKn3lNNV\#.vv64zoxxP (detailing recruitment stream from Topolobampo, Sinaloa, Mexico to Louisiana crawfish industry).

${ }^{132}$ See, e.g., Lee, supra note 129, at 73 (noting workers' reluctance to report abuses out of fear of retaliation and summarizing immigration protections and measures taken in civil litigation to protect workers against future retaliation).

133 Notably, the risk is not misperceived - workers have experienced or witnessed retaliation and thus are informed when they seek to avoid it. See Alexander \& Prasad, supra note 114, at 1098 (explaining that low-wage workers surveyed in a large-scale study did not complain about legal problems because "they feared retaliation or doubted the efficacy of claims making," and that "these beliefs were rational" because $43 \%$ of workers experienced retaliation for a past claim they had made and $14 \%$ of workers had witnessed a coworker being retaliated against).

${ }^{134}$ See Hall, supra note 10, at 534 ("When they can no longer tolerate the conditions, most H-2A workers will 'vote with their feet' and leave silently rather than complain."); $c f$. Alexander \& Prasad, supra note 114, at 1090-91 (summarizing findings that "less powerful and economically stable workers appear less likely to engage in claiming behavior" and that workers who have "held their job for fewer than twelve months were also less likely to have made a claim about a workplace problem during that time").

${ }^{135}$ Hall, supra note 10, at 523; cf. Weil \& Pyles, supra note 123, at 83-84 (noting that workers often take legal action after they are no longer employed with the particular employer, "thereby lowering the cost of complaining at that point").

${ }^{136}$ See, e.g., Lee, supra note 62, at 56 ("Just like guest workers, undocumented workers are often required to accept jobs with low wages, hazardous working conditions, and high productivity requirements because of their tenuous immigration status. Undocumented workers, however, usually have more bargaining power than guest workers because they 
differences, as one an advocate has recalled:

I am always struck when a group of non-H-2A farmworkers discusses the situation of H-2A workers; at least one always says the H-2A workers are "like slaves," even if that person is him or herself undocumented. The other workers in the group always readily agree with this assessment. Non-H-2A migrant farmworkers who have interacted with $\mathrm{H}-2 \mathrm{~A}$ workers probably grasp the dynamics of the system more readily than anyone else. ${ }^{137}$

It is thus the very nature of the $\mathrm{H}-2 \mathrm{~A}$ program itself, with its lack of visa portability, that leaves $\mathrm{H}-2 \mathrm{~A}$ workers particularly at risk of experiencing retaliation on a scale generally not experienced by other groups of vulnerable workers. When this is combined with the linguistic and cultural differences that can cause misperceptions in the nature of the U.S. legal system, as well as the extreme isolation in which workers live and work while in the United States, it is no surprise that the likelihood of them choosing to speak out and take action about their mistreatment, in whichever form that occupies, is all the more diminished.

\section{Structural Barriers}

Assuming that, in spite of the above-mentioned barriers, an $\mathrm{H}-2 \mathrm{~A}$ worker does wish to do something about his mistreatment, there remain additional hurdles to actually vindicating his rights. Below, I discuss the complications brought about by the legal and enforcement structures available to $\mathrm{H}-2 \mathrm{~A}$ workers, first focusing on governmental enforcement options and then turning to two hurdles a worker would encounter should he wish to directly enforce his rights through civil litigation.

\section{a. Weak Government Enforcement}

The first line of defense against such legal violations should be the administrator of the H-2A program itself, the U.S. government. Unfortunately, enforcement agencies within the government-particularly within U.S. DOL - are largely ineffective, both at preventing the problems in the first place and remedying problems after legal violations have occurred.

As I noted above, employers have been turning to the H-2A program in record numbers. ${ }^{138}$ Many of them, however, have been approved to participate in the program by U.S. DOL despite failing to make the required

have the freedom to change jobs, albeit with difficulty.").

${ }^{137}$ Hall, supra note 10, at 536.

${ }^{138}$ See supra notes 26-40 and accompanying text.. 
good faith efforts at recruiting U.S. workers. ${ }^{139}$ Lapses in government oversight over the $\mathrm{H}-2 \mathrm{~A}$ program are not limited to problems with the recruitment of U.S. workers, however. It is well-documented that U.S. DOL continues to approve employers' applications to bring in $\mathrm{H}-2 \mathrm{~A}$ workers even when they have been found to violate $\mathrm{H}-2 \mathrm{~A}$ regulations in the past. ${ }^{140}$ In the unlikely event that U.S. DOL actually takes the step of debarring-or temporarily banning - an employer from the $\mathrm{H}-2 \mathrm{~A}$ program due to violations of regulations, ${ }^{141}$ it is not hard for the employer to get around the prohibition, as it can file an application under a new entity or individual's name or address, thereby evading any suspicion and easily obtaining approval to import more workers. ${ }^{142}$ Because different units within U.S. DOL are involved at different stages within the $\mathrm{H}-2 \mathrm{~A}$ process, the problem is often one of a lack of inter-agency coordination. Specifically, it is the Wage and Hour Division ("WHD") that conducts any investigations into regulatory compliance and would have the authority to penalize employers, including by debarring them, ${ }^{143}$ but it is the Employment and Training Administration that reviews and approves new applications by employers. When one also considers that DHS and the U.S. Department of State, via its consulates and

139 See supra notes 60-61 and accompanying text.

${ }^{140}$ See ClOSE TO SLAVERY, supra note 10, at 39-40 (summarizing inaction by U.S. DOL in the face of employer violations, including critique made by the Office of the Inspector General about failure to suspend employers from participating in program); see also Ken Bensinger et al., Employers Abuse Foreign Workers. U.S. Says, By All Means, Hire More., BuZZFEED, May 12, 2016, https://www.buzzfeed.com/kenbensinger/thepushovers?utm term=.rlPx2A99N\#.siBLGmgg9 (detailing numerous egregious examples of such cases and explaining bureaucratic hurdles within U.S. DOL that resulted in few actions to ban employers from guestworker programs) [hereinafter U.S. Says, Hire More].

${ }^{141}$ See 29 C.F.R. $\$ 501.20$ (allowing for debarment of "an employer or any successor in interest to that employer" for a period of up to three years). In the past, very few employers were debarred. See Close TO Slavery, supra note 10, at 39 (noting that, from approximately 2011 to 2013, U.S. DOL debarred only 22 H-2A employers). In more recent years, at the close of the Obama administration, that does appear to have slightly improved. See OfFice of Foreign Labor CERTIFICATION, EMPloyment \& TRAining AdMin., U.S. DEP'T OF LABOR,, Program Debarments, https://www.foreignlaborcert.doleta.gov/pdf/Debarment_List_Revisions.pdf (last visited October 30, 2017) (displaying 33 H-2A employers on the debar list, with an additional three employers on a permanent debar list). Given that proportionally few employers are even investigated and even fewer are found to violate regulations to begin with, see infra notes 146-149 and accompanying text, the fact that so few employers with violations are being debarred truly shows the extent of the repeat violator problem.

142 See U.S. Says, Hire More, supra note 140 ("The few companies that do get debarred often seem to view it as little more than a minor nuisance. Agency rules make it easy for debarred companies to simply reinvent themselves, filling out new visa request under a different name or address, and quickly winning agency approval to bring in more workers.").

143 See 29 C.F.R. § 501.20(a) (giving authority to WHD Administrator to debar employers pursuant to this regulation). 
embassies, also play roles in approving the visas for workers (after the U.S. DOL certifies the employer's job order), the problem grows in magnitude. It is not simply that a few bad employers are slipping through the cracks, it is that the government appears to leave the door wide open for them.

Once problems have occurred, the government is similarly illequipped to remedy the legal violations. As a general matter, the availability of government resources for enforcing the labor and employment rights of workers in the United States has declined over several decades. ${ }^{144}$ While there was an increase in resources during the Obama administration, ${ }^{145}$ the results of such an increase in terms of enforcement action were mixed. An analysis conducted by the advocacy group Farmworker Justice of data related to WHD enforcement actions between 2005 and 2008, during the Bush administration, and between 2010 and 2013, during the Obama administration, found a slight decline in the number of agricultural investigations during the latter time period. ${ }^{146}$ While the number of hours spent on cases and the amount of wages and penalties assessed against employers increased during the Obama administration, ${ }^{147}$ particularly with investigations into $\mathrm{H}-2 \mathrm{~A}$ employers, ${ }^{148}$ the fact remains that the vast majority of employers are not investigated and are left free to conduct business as usual. ${ }^{149}$

144 See Close to SLAVERY, supra note 10, at 39 (citing 14\% decline in wage and hour investigators from 1974 to 2004 , but an increase from 56.6 million to 87.7 million workers whose rights are protected by the Fair Labor Standards Act during that same time period); see also Weil \& Pyles, supra note 123, at 62 (same, with respect to the number of workers covered by the WHD).

${ }^{145}$ In 2009, WHD increased its number of investigators by nearly one third, making 250 new hires. See Press Release, U.S. DEP'T OF LABOR, Statement by US Secretary of Labor Hilda L. Solis on Wage and Hour Division's increased enforcement and outreach efforts (November 19, 2009), https://www.dol.gov/opa/media/press/whd/whd20091452.htm.

146 FARMWORKER JUSTICE, U.S. DEPARTMENT OF LABOR ENFORCEMENT IN Agriculture: More Must Be Done to Protect FARmworkers Despite Recent IMPROVEMENTS 3 (2015), available at https://www.farmworkerjustice.org/sites/default/files/FarmworkerJusticeDOLenforcement Report2015\%20\%281\%29.pdf (noting 6,125 cases during the final four years of the Bush administration and 6,119 during the four-year sample of the Obama administration).

${ }^{147} \mathrm{Id}$. at $4(41.2 \%$ increase in case hours, $219.1 \%$ increase in assessed penalties, and $127.4 \%$ increase in assessed wages in agricultural investigations as a whole).

${ }^{148} I d$. at 9 (113\% increase in investigations under the $\mathrm{H}-2 \mathrm{~A}$ program, $236.4 \%$ increase in case hours, $1,105.3 \%$ increase in penalties assessed, and $95.1 \%$ increase in $\mathrm{H}-2 \mathrm{~A}$ cases with violations). As the authors of the report note, however, it's likely that part of the increase was simply due to the increase in the H-2A program's use during the relevant time periods. See id. at 8 ("Over the eight years under consideration (2005-2013), usage of the H-2A program grew, from 48,336 agricultural positions certified to 98,813, an increase of $104 \%$. Increased enforcement activity over this time period may correlate at least partially to the program's robust expansion.").

${ }^{149} I d$. at 5 (noting that, during the Obama administration time period at issue, there were approximately 566,469 farms employing farmworkers, but only 6,119 investigations). 
More broadly speaking, however, the very structure of the administrative remedies in place to address problems within the $\mathrm{H}-2 \mathrm{~A}$ program renders them largely one-sided. As one observer has analyzed in detail, the mechanisms in place to address violations experienced by $\mathrm{H}-2 \mathrm{~A}$ workers leave much room for discretion on the part of investigators, while any employers who file a complaint about issues they experience during the process of applying for $\mathrm{H}-2 \mathrm{~A}$ workers, or about the results of any WHD investigations, are provided with much greater protections. ${ }^{150}$ In short:

[U.S. DOL's] regulations do not treat H-2A workers nearly as well as their employers. Under these regulations, an aggrieved grower has the right to a reasoned decision from the [Administrative Law Judge] within a definite, and frequently very brief, time period. In contrast, an aggrieved $\mathrm{H}-2 \mathrm{~A}$ worker is free to make a complaint to [U.S. DOL], but is not even entitled to a report on the status of that complaint. ${ }^{151}$

To complicate the situation even further, H-2A workers are present in the United States for only a short period of time. This makes the enforcement situation even more dire. Workers are reluctant to complain about work conditions while still employed by and residing on the property of their employer, ${ }^{152}$ and it is unlikely that an investigation will be initiated or successfully completed while workers are back in their home countries. ${ }^{153}$ At the back end, there are further bureaucratic problems: even if the investigation has a positive outcome and the U.S. DOL finds that workers are owed wages, there are enormous hurdles in sending those funds to workers in their home countries, with the likelihood of government officials navigating that system directly very low. ${ }^{154}$

150 See Holley, supra note 19, at 598-603. Some of the regulatory provisions cited by Holley have been modified slightly, or re-numbered, but the substance remains largely the same.

${ }^{151} I d$. at 603.

152 See, e.g., supra note 115.

${ }^{153}$ My experience has been that some WHD investigators may be willing to attempt to communicate with workers by phone when they are back home, but this is certainly not the norm-most interviews are conducted in-person when an investigator visits the place of employment. Even in one case in which an investigator spoke to a worker back in his home country, this was only able to happen because I made the logistical arrangements and directly facilitated the communication via a conference call.

${ }^{154}$ U.S. DOL normally sends a notice and form to be completed regarding the wages recovered to the worker by mail—so U.S. DOL would have to have the worker's mailing address back in their home country and be able to successfully send correspondence there (and have the worker return such a form successfully as well). Moreover, U.S. DOL normally sends a check in U.S. dollars to workers, a method of distributing funds that would not be useful to impoverished migrant workers, who lack bank accounts, in foreign countries. In my experience, some regional offices of U.S. DOL have been open to sending funds to 
In short, H-2A workers seeking help from the U.S. government to enforce the rights the government and their employer have promised to uphold have an uphill battle. This is in keeping with H-2A workers' outsider status: they are nameless at the beginning, not the intended beneficiaries of the framework that purportedly exists to protect them, and are unlikely to get help from the government for egregious abuses they may suffer while in this country.

\section{b. Restrictions on Counsel's Scope of Representation}

Effectively shut out by government enforcement agencies, H-2A workers may turn to another option: enforcing their rights directly against their employers via civil litigation. However, workers who choose such an approach also face a difficult situation. This is because $\mathrm{H}-2 \mathrm{~A}$ workers are generally limited in terms of their options for legal counsel and the scope of representation such counsel may provide.

As an initial matter, the task of representing $\mathrm{H}-2 \mathrm{~A}$ workers is a complicated one, as it involves representing (generally) non-English speakers who are located in rural areas and migrate to and from their homes in foreign countries. This does not render representation impossible, ${ }^{155}$ but litigating with clients across borders is not something that some attorneys have done or are competent to do. Moreover, while federally-funded legal aid officesformally known as grantee organizations of the Legal Services Corporation ("LSC"), the federal agency that funds legal aid - are able to represent H-2A workers, the scope of that representation is limited in two key ways. ${ }^{156}$

workers via international bank-to-bank wire transfer. But the logistics of such an option are numerous, resulting in a de facto requirement of attorneys or other representatives being involved in the process. To begin, workers are often required to travel long distances from their rural homes to cities that have banks, and usually must have some amount of money available to pay to open and set up the account. Furthermore, someone assisting such a worker would have to give detailed instructions to the worker on what type of account to open (not all accounts are able to receive international wire transfers), and on the accountand bank-related information that the worker must gather in order for the transfer to be initiated. If there is some error in the transfer resulting in the funds being returned (e.g., if an account number was written incorrectly, the account was the wrong type of account, etc.), the worker is not typically notified - other than seeing that no money was received - and it can be a complicated process to have government officials verify that the money was returned, determine the error, and re-initiate the transfer. In short, there is currently no realistic way that a worker in his home country would be able to recover these funds by directly communicating with U.S. DOL.

${ }^{155}$ See, e.g., infra note 258.

${ }^{156}$ By focusing on LSC programs in this article, I do not intend to assert that only LSC grantee organizations represent H-2A workers. Many state-level farmworker programs are "unrestricted," meaning they are not LSC grantee organizations and are not subject to the restrictions described in the article. See, e.g., FlORIDA LEGAL SERVS., Our Projects, 
First, H-2A workers may only receive legal assistance from LSC grantee organizations if they have been "admitted to, or permitted to remain in" the United States on an $\mathrm{H}-2 \mathrm{~A}$ visa, ${ }^{157}$ and may only receive legal assistance on the following subjects: wages, housing, transportation, and "employment rights as provided in the worker's specific contract under which the nonimmigrant worker was admitted" to the United States. ${ }^{158}$ While the catch-all reference to employment rights can be read broadly, and while such language would cover the scope of problems discussed in this article, it would restrict LSC grantee organizations from representing workers regarding other significant problems they may experience. For example, workers who are victims of recruitment abuse or fraud in their home countries, but do not end up migrating to the United States on a visa for the promised job, would not be covered by the regulation. Workers who are retaliated against by not being re-hired for subsequent seasons would similarly be out of luck: even if they had been H-2A workers in the past, such retaliation is forward-looking, and thus not related to a contract under which they were present in the United States. The requirement of having been admitted to the United States on an $\mathrm{H}-2 \mathrm{~A}$ visa that relates to the legal problems the worker experienced, therefore, operates to bar numerous individuals from accessing legal representation. ${ }^{159}$

Notably, recent proposed legislation would dramatically expand the

http://floridalegal.org/our-projects/ (last visited August 28, 2017) (describing Migrant Farmworker Justice Project); NC JUSTICE CTR., History of the Workers' Rights Project, http://www.ncjustice.org/?q=workers-rights/history-workers-rights-project (last visited August 28, 2017) (describing litigation on behalf of $\mathrm{H}-2 \mathrm{~A}$ and $\mathrm{H}-2 \mathrm{~B}$ workers). There are also regional or national groups that advocate for and have litigated on behalf of $\mathrm{H}-2 \mathrm{~A}$ workersfor example, the Southern Poverty Law Center filed multiple class action lawsuits on behalf of H-2A workers in the mid-2000s. See ClOSE TO Slavery, supra note 10, at 20. Nevertheless, the LSC restrictions discussed below, see infra note 163 and accompanying text, are important to consider because of the sheer breadth of LSC grantee organizations. LSC is the largest funder of civil legal services in the United States. See LEGAL SERVS. CORP., Who We Are, https://www.lsc.gov/about-lsc/who-we-are (last visited August 28, 2017). There are over 800 LSC grantee offices nationwide. See LEGAL SERVS. CORP., Quick Facts, https://www.lsc.gov/quick-facts (last visited August 28, 2017). Moreover, LSC dedicates specific grants to serving agricultural workers in particular. See LEGAL SERVS. CORP., Basic Field Grant, https://www.lsc.gov/grants-grantee-resources/our-grantprograms/basic-field-grant (last visited August 28, 2017) ("Overview" section). For a stateby-state breakdown of grant awards, including the agricultural worker grants, for 2017, see LEGAL SERvs. CORP., 2017 GRANT AWARD DECISIONS, available at https://lsclive.box.com/shared/static/d9laahldv6jucmkgopuc3ko59j0f5fix.pdf.

15745 C.F.R. $\$ 1626.11(\mathrm{a})$.

${ }^{158}$ Id. $\S 1626.11(\mathrm{c})$.

${ }^{159}$ Both examples given in the text are drawn from real cases I have encountered in my time representing $\mathrm{H}-2 \mathrm{~A}$ workers, one while at a LSC grantee organization, and the other in my current position. 
restrictions even more: the Better Agricultural Resources Now Act of 2017 would amend the INA to allow LSC grantees to only represent $\mathrm{H}-2 \mathrm{~A}$ workers if "the alien is present in the United States at the time the legal assistance is provided" and would impose an alternative dispute resolution requirement before any legal assistance can be provided to H-2A workers. ${ }^{160}$ Given the drawn out nature of litigation, not to mention that many H-2A workers may strategically choose to contact lawyers about legal problems only after they have completed their period of employment, ${ }^{161}$ the physical presence restriction would be a significant impediment to LSC grantees in comprehensively representing $\mathrm{H}-2 \mathrm{~A}$ workers. The dispute resolution requirement would have a similar effect: it would be much more difficult for an $\mathrm{H}-2 \mathrm{~A}$ worker to have a successful result in such a context without legal representation, both on the merits (i.e., failing to recognize and thus possibly waiving cognizable legal claims he may have), and in terms of navigating the process at all. ${ }^{162}$

More generally, the LSC regulations impose restrictions on representation across the board, regardless of the client, that would impact the possible advocacy on behalf of H-2A workers. Specifically, LSC grantee organizations are prohibited from litigating class actions, organizing work, and lobbying. ${ }^{163}$ This trio of restrictions is undeniably intentional in its effect, seeking to undermine efforts at systemic changes. The class action restriction also impedes broader legal challenges within the civil litigation context specifically_-for example, a class action lawsuit may be a more appealing

${ }^{160}$ Better Agriculture Resources Now Act, H.R. 641, 115th Cong. § (j) (2017). This issue has arisen in the past; in the 1990s, the LSC created the Erlenborn Commission to determine whether grantees were already so restricted based on regulatory language allowing for representation of H-2A workers who were "present in the United States." The Commission ultimately concluded in the negative, thus allowing for transnational representation. See LEGAL SERvs. CORP., ERLENBORN COMM'N REPORT, available at https://www.lsc.gov/sites/default/files/LSC/pdfs/jnecrpt.pdf. Moreover, H-2A workers are not the only subjects of possible restrictions; in the past, Congress sought to prohibit LSC grantee attorneys who were representing welfare recipients from making legal arguments challenging existing welfare law, which the Supreme Court ultimately determined to be an unlawful restriction of such attorneys' First Amendment rights. See Legal Services Corp. v. Velasquez, 531 U.S. 533 (2001).

161 See supra note 132 and accompanying text.

162 The proposed legislation does not appear to foreclose the employer's right to have counsel during such a dispute-resolution process. One can only imagine the outcome of a mediation between an employer who is represented by an attorney and an H-2A worker without a lawyer.

${ }^{163}$ See LEgAl SERVS. CORP., About Statutory Restrictions on LSC-funded Programs, http://www.1sc.gov/about-statutory-restrictions-lsc-funded-programs (last visited June 27, 2017). Notably, the restrictions are imposed on the grantee organization, meaning that the grantee cannot take such actions even if it were being done so using non-LSC funding sources. See id. 
option for workers who prefer to retain some anonymity and thus simply proceed as a class member, rather than being a named plaintiff in a straightforward civil case. ${ }^{164}$ Class actions also provide financial benefits by increasing potential damages due to a greater number of claims, thereby producing a greater impact on the employer and industry more generally. ${ }^{165}$ Despite these restrictions, straightforward, i.e. non-class action, civil litigation on behalf of named parties remains untouched, and LSC grantee organizations may represent $\mathrm{H}-2 \mathrm{~A}$ workers in that capacity, so long as the other substantive requirements are satisfied.

\section{c. Limited Legal Claims}

Assuming workers do overcome these structural hurdles and file a lawsuit against their employers, a final barrier exists: the legal claims available to them are restricted in very specific ways.

As an initial matter, $\mathrm{H}-2 \mathrm{~A}$ workers are expressly excluded from the federal statute that provides protections to other farmworkers in the United States, the Migrant and Seasonal Agricultural Worker Protection Act ("AWPA"). ${ }^{166}$ Because of this exclusion from AWPA, H-2A workers who experience legal violations are generally left to pursue claims premised on a violation of state law, which would relegate them to litigation in a generally unfavorable state forum. ${ }^{167}$ Given that $\mathrm{H}-2 \mathrm{~A}$ workers tend to be employed in higher numbers in the southern United States ${ }^{168}$ the practical result would be to have to appear in a southern, rural courthouse as foreign, non-English speaking plaintiff - a rare sight in such locations - and to take on local employers and often powerful industries, all in courts headed by elected

${ }^{164}$ To illustrate the potential benefits, consider one recent example of a class-action filed by an unrestricted farmworker program: in that case, two H-2A workers have filed a federal lawsuit against a blueberry farm in Washington, and seek to represent a class of more than $600 \mathrm{H}-2 \mathrm{~A}$ workers in total. See Press Release, Columbia Legal Servs., Class Action Filed Against Munger Brothers and Sarbanand Farms for Pattern of Threats and Intimidation That Violated Federal and WA State Labor Laws (Jan. 25, 2018), http://columbialegal.org/class-action-filed-against-munger-brothers-and-sarbanand-farmspattern-threats-and-intimidation.

165 See Dias-Abey, supra note 114, at 26 (noting that class actions provide a benefit for plaintiffs' counsel because they aggregate claims, thereby increasing damage awards and having "a much bigger specific and general deterrence effect").

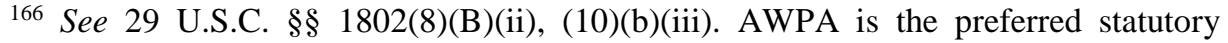
abbreviation of farmworker advocates; the statute tends to be abbreviated as "MSPA" by enforcement agencies, such as WHD. See WAGE AND Hour Div., U.S. DEP'T OF LABOR, Migrant and Seasonal Agricultural Worker Protection Act (MSPA), https://www.dol.gov/whd/mspa/ (last visited November 2, 2017).

167 See Holley, supra note 19, at 608-13.

168 See supra notes 31-33 and accompanying text. 
judges. ${ }^{169}$ In sum, state courts represent a particularly stark power disadvantage for the workers.

How does this limitation practically impact the legal remedies for violations of H-2A workers' rights? In the case of wage violations, it means that workers can be paid just over half as much as they are legally supposed to be paid per hour ${ }^{170}$ and still be without access to a federal court, a particularly absurd result given that the AEWR, the effective minimum wage for H-2A workers, is set by a federal agency implementing federal regulations and statutes. ${ }^{171}$ The consequences of this unfair treatment are significant - even underpayment by several dollars per hour over the course of a season can amount to a significant amount of money, particularly for $\mathrm{H}$ 2A workers, resulting in high stakes for the workers.

Workers may have alternative options for getting into a federal forum in cases of very specific types of mistreatment. For example, H-2A workers may have remedies under federal statutes including the Trafficking Victims Protection Act ("TVPA"), the Racketeer and Influenced Corrupt Organization Act ("RICO"), or Title VII or equivalent anti-discrimination statutes. ${ }^{172}$ However, TVPA, RICO, and discrimination claims tend to target relatively narrow-and egregious-types of behavior. ${ }^{173}$ Such legal violations certainly arise in the context of $\mathrm{H}-2 \mathrm{~A}$ work, but not all wrongs experienced by $\mathrm{H}-2 \mathrm{~A}$ workers can easily be fit into these boxes, and the most common types of violations, including underpayment and the imposition of recruitment fees, do not give rise to such claims on their own. ${ }^{174}$

${ }^{169}$ For a palpable example of bias against H-2A workers in state courts in the south, see Holley, supra note 19, at 610-12 (summarizing a preemptive lawsuit filed by a tobacco grower in Kentucky state court, where judges are elected, against H-2A workers whose rights had been violated and subsequent efforts by Congressional representative to introduce legislation to restrict H-2A workers' choice of forum and U.S. senator's threats to investigate legal services agency representing H-2A workers for misuse of federal funds).

${ }^{170}$ Because the AEWR currently ranges between $\$ 10.69$ per hour and $\$ 14.12$ per hour, see supra note 67 and accompanying text, an H-2A worker would have to be significantly underpaid to have an effective wage rate falling below the federal FLSA minimum wage of $\$ 7.25$ per hour, thus providing for a federal claim. The case law finding FLSA violations if a worker is not reimbursed for certain job-related, pre-departure expenses in the first workweek, see supra note 73, is thus a critical development, as that allows workers in a case involving what would otherwise only be violations of the AEWR throughout the season to have a basis for federal court jurisdiction.

${ }^{171}$ While a similar analysis may be true of other low-wage workers on a superficial level-workers in states with a minimum wage above $\$ 7.25$ per hour would similarly be relegated to state court unless their wages fall below the federal threshold - in those cases, those workers are only looking to their relevant state law to show a legal violation, unlike $\mathrm{H}$ $2 \mathrm{~A}$ workers looking at the federally-set AEWR.

${ }^{172}$ See Lee, supra note 129, at 50-67.

173 See id. at 74.

174 The payment of recruitment fees may be a useful component to a claim for forced 
In sum, H-2A workers whose rights have been violated face significant structural barriers to pursuing legal remedies for such violations. ${ }^{175}$ The likelihood that a government enforcement agency will provide redress for these wrongs is minimal. Workers have few realistic options for counsel, and the scope of such counsel's activities and their legal claims are limited, both due to federal law. This is all compounded by the high stakes workers face if they decide to speak out: retaliation is a very real risk, and operates on a scale of significance not experienced by other workers in the United States. Despite these hurdles, I believe that civil litigation can provide a unique opportunity for vindicating the rights of $\mathrm{H}-2 \mathrm{~A}$ workers and empowering them through the process. In the remainder of this article, I provide a vision for how to make this a reality, exploring the opportunities for practitioners to engage in client-centered lawyering during litigation, with the goal of amplifying the voices of the H-2A workers they represent.

\section{A VISION OF REPRESENTATION FOR H-2A WORKERS IN CIVIL LITIGATION}

Civil litigation is not a new approach to vindicate the rights of marginalized communities. However, in the decades after an impact litigation strategy led to significant legal victories during the social movements of the 1950 s and 1960s, it began to fall out of favor with social-justice minded practitioners. In part, this was due to a critique that litigation did not best serve the marginalized communities it purported to help; critics questioned whether operating within the very political system that led to such disempowerment was the best way to lift up those communities at all. ${ }^{176}$ Others questioned whether civil rights impact litigation posed ethical concerns for plaintiffs' attorneys, in light of potentially diverging goals of the

labor under the TVPA, but would not give rise to a claim independently; rather, a plaintiff bringing such a claim would also generally make allegations regarding coercive or threatening behavior on the part of the defendant. See Lee, supra note 129, at 52-53 (summarizing forced labor claims under the TVPA).

${ }^{175}$ For a detailed review of another guestworker program that also imposes a framework causing significant access to justice issues that in many ways outpace the problems of the H2A program, the J-1 visa program, see Janie A. Chuang, The U.S. Au Pair Program: Labor Exploitation and the Myth of Cultural Exchange, 36 HARV. J. L. \& GENDER 269 (2013).

176 See, e.g., Ashar, supra note 121, at 1904-05 ("In light of the inherent indeterminacy of legal reasoning, using adjudication to define and resolve social and economic disputes by left lawyers had the effect of legitimizing and reinforcing an established political structure, the same structure constructed for managing and oppressing poor people."); see also DiasAbey, supra note 114, at 11 (summarizing "socio-legal . . criticisms about the use of litigation as a tool for progressive change"). Ashar recognizes the discomfort such effects can have on the lawyers in such circumstances, describing "progressive public interest lawyers" as "conflicted agents of the legal system, sympathetic to the methods and goals of resistance movements but bound by the forms of the legal establishment." Id. at 1880. 
funders of civil rights organizations and the individuals whose rights were at issue in the cases themselves. ${ }^{177}$ Such critiques were soon followed by the poverty lawyering scholarship of the 1980s and early 1990s that provided powerful anecdotes of "lay lawyering," in which clients or community advocates were often more effective at engaging with and confronting legal decision-makers than lawyers. ${ }^{178}$

Against this backdrop, practitioners tended to take a step away from litigation as a central mobilizing strategy and turned instead towards a broader approach in representing marginalized communities. Often referred to as community lawyering, this style of advocacy has been particularly favored by attorneys working with and on behalf of low-wage and immigrant workers. Given this tendency, it is worth examining what such models have looked like and whether any lessons can be drawn from these approaches for the purposes of representing $\mathrm{H}-2 \mathrm{~A}$ workers.

In the following sections, I first explore the role and views of litigation among community lawyering scholars and practitioners, with a focus on two particular cases of low-wage worker advocacy: restaurant workers in New York and day laborers in Los Angeles. With these examples in mind, I then turn to a specific framework for how to effectively advocate for H-2A workers in a civil litigation context, with a detailed exploration of how to preserve and amplify client voice at various stages in the life of a lawsuit. Finally, I go beyond the confines of litigation itself, and explore the benefits and methods of empowerment that are available beyond a successful resolution of an H-2A worker's particular claims, specifically the opportunity for forward-looking remedies in cases as well as the downstream benefits that litigation can provide.

\section{A. Existing Views of Litigation in Low-Wage Worker Advocacy}

Community lawyering is a method of representation by which

\footnotetext{
177 See Derrick A. Bell, Jr., Serving Two Masters: Integration Ideals and Client Interests in School Desegregation Litigation, 85 YALE L.J. 470, 490 (1976) (acknowledging possible conflict if interests of funders diverge from interests of clients being served); see also Scott L. Cummings, Rethinking the Foundational Critiques of Lawyers in Social Movements, 85 FORDHAM L. REV. 1987, 1992-93 (2017) (analyzing Bell's argument).

${ }^{178}$ See, e.g., Ashar, supra note 121, at 1907 ("The underlying theory (or implication) of social change was that poor people could transform communities and entrenched legal systems through their assertions of power against bureaucrats and lawyers. The themes of legal academic literature were manifested in the field by a move away from professionalism to 'lay lawyering' - poverty lawyers and community advocates less focused on litigation and law reform as a means of redress and instead toward participation in local, non-legal efforts for social change."); see also Piomelli, supra note 15, at 457-86 (summarizing leading literature and scholarship on "collaborative lawyering").
} 
attorneys work together with, and advocate on behalf of, a "community"179 in order to empower that group, and do so by using a broad set of legal strategies. ${ }^{180}$ The community - whether that is a local organization, a broader social movement, or some other official or unofficial group-is represented in a client-centered manner, ${ }^{181}$ with the lawyer serving less as the sole leader and decider of the legal representation, but rather more of an ally to the community's cause. ${ }^{182}$ Litigation can have a role in a community lawyering practice, but it is not a panacea; if anything, litigation is a means to the end of empowering the community members beyond the frame and timeline of any particular court case. Directly engaging with the legal system "is one of the many tools in the arsenal of social change tactics," 183 and a victory in that system is not necessarily the goal. Rather, community "lawyers measure the success of their work in relation to how much power the groups develop and how much closer it brings them to achieving their vision." ${ }^{84}$ Indeed, some

${ }^{179}$ Some scholars have noted that the use of the term "community" in this context can be problematic. As Jennifer Gordon has observed, assuming that there is "a single unit called "the community" opens the door "to the dangers of assuming that people who live near each other and share markers of race or ethnicity are bound by a common conception of their interests." Gordon, supra note 120, at 2135. Instead, Gordon looks favorably upon those lawyers who "focus on organizations committed to a particular (albeit inevitably contested) set of goals and view of justice," and who recognize "that organizations engaged in the fight for social change cannot focus on race or class exclusively but must pursue racial and economic justice hand in hand." Id.

${ }^{180}$ For example, a lawyer can engage in "direct representation of the groups (or their members) in litigation, advocacy, or transactional work," or it can be a "more informal or fluid" relationship between lawyer and community organization. Gordon, supra note 120, at 2141.

181 See Cummings, supra note 177, at 1989 ("Prescriptively, the literature suggests that lawyers should represent movements in client-centered terms, using the law to ensure that 'the movement takes the lead."').

182 Ascanio Piomelli's account of his representation of community members in East Palo Alto, CA provides a clear vision of lawyer as ally. He describes his role in community mobilization efforts at public city meetings as follows:

This initial skirmish over the appointments to the Rent Board also refined my understanding of how to collaborate successfully with clients. It led me to abandon my initial reluctance to speak at public meetings. I soon recognized that, as long as I was careful to ensure that my clients also spoke and I did not monopolize the spotlight, my public addresses led clients to view me as more firmly on their side. Silence on my part was perceived not as respectful deference but as aloofness or indifference. I soon realized that if I wanted to be a collaborative team player, my clients expected me to carry my weight in the public arena too. Moreover, our adversaries might have construed my silence as fear, incompetence, or unwillingness to confront their actions.

Piomelli, supra note 15, at 509-10.

183 Gordon, supra note 120, at 2141.

${ }^{184}$ Id.; see also Ashar, supra note 121, at 1917 ("The organizers and workers themselves 
observers have noted how litigation can, in fact, harm community mobilization and advocacy efforts. ${ }^{185}$

Two case studies demonstrate this style of lawyering, with litigation as one of the several tactics used by low-wage worker advocates as part of a broader organizing strategy. The first concerns a law school clinic's representation of Restaurant Opportunities Center of New York ("ROCNY"), a Manhattan-based workers' center whose members worked in the restaurant industry. ${ }^{186}$ The representation was focused on a ROC-NY campaign against a large corporate restaurant chain. ${ }^{187}$ In large part, the work done by the lawyers - in this case, the clinic and its students-resembled typical legal work. Students researched legal claims related to underpayment experienced by workers, interviewed clients, and drafted and filed a complaint in federal court. ${ }^{188}$ They litigated the federal case and also represented workers in an investigation conducted by the National Labor Relations Board. ${ }^{189}$ They also played a key role in responding to crises brought about because of the ongoing organizing and legal activity, including investigating allegations of retaliation experienced by workers and "communicating quickly and strongly with opposing counsel" about such incidents. ${ }^{190}$ In this last instance, the students most embodied the lawyer-asally role: by reassuring the workers that the lawyers would not abandon them in moments of vulnerability, the workers would be "more likely to participate in campaign activities and resist employer coercion."191

defined the problem area, chose targets within the industry, and directed public protest and media advocacy with lawyers supporting these activities through affirmative and defensive legal action.").

185 See Piomelli, supra note 15, at 502 (recalling concern that use of litigation in East Palo Alto, CA rent control dispute could have unintended consequence of providing "County elites" with another forum to promote their "gentrification agenda"); Gordon, supra note 122, at 439-40 (noting dangers of over-relying on legal services within the context of lowwage worker mobilization).

${ }^{186}$ See generally Ashar, supra note 121. Notably, Ashar terms the style of representation in this case study "public interest" lawyering, specifically within the context of movement organizing. See, e.g., id. at 1922 ("Public interest lawyers and movement organizations have much to gain from collaboration ... "). For an explanation of workers' centers and a background on their rise in the United States, see id. at 1892-95.

187 See id. at 1899. Ashar notes that, part of the reason why the clinic ended up representing ROC-NY was because of the prohibitions imposed on federally-funded legal services agencies that kept such organizations from representing undocumented workers as well as any type of litigation other than direct services. See id. In other words, this case is an example of the very real effect of the LSC restrictions operating to restrict legal options for workers. See supra section II(A)(2)(b).

${ }^{188}$ See Ashar, supra note 121, at 1901-02.

${ }^{189}$ See id. at 1913-14.

${ }^{190} \mathrm{Id}$. at 1913.

${ }^{191}$ Id. 
In other ways, however, the lawyers' role was complicated because of their very status as lawyers (or soon-to-be lawyers). In particular, the duties imposed by the rules of professional responsibility proved difficult to manage in a campaign defined by "a tripartite relationship between lawyers, workers, and organizers." 192 The lawyers had to ensure that third parties-i.e., the organizers - would not influence clients' legal decisionmaking and also had to carefully navigate organizer involvement in lawyer-client conversations so as to not risk the loss of attorney-client privilege. ${ }^{193}$ In response, the lawyers chose an adaptive strategy; rather than "reject[ing] the influence of the organizers," the lawyers chose to "learn to discern the boundaries between lawyer-client, lawyer-organizer, and client-organizer decision making."194 Beyond the internal members of the campaign, the lawyers also experienced difficulties in the context of the federal litigation in light of the presiding judge's hostility to the use of the lawsuit as part of a broader campaign, which had an effect on several discovery issues. ${ }^{195}$ In one notable encounter, after being confronted with a proposed confidentiality agreement by defense counsel, which the lawyers viewed as counter-productive to the goals of both the clients (who refused to sign it) and the campaign more broadly, the judge lectured the legal team on what their role should be: "He said derisively that the lawyers were not to use a case in his court to advance a cause or to transform overall conditions in the industry. He instructed the team to litigate the individual case and not to be unreasonable in negotiations."196 The organizers, not operating in a framework of professional responsibility and ethical obligations, did not face the same type of constraints; it was only the lawyers who were directly impacted by these additional considerations. ${ }^{197}$

What does the experience of the clinic tell us about the role of lawyers and litigation in community lawyering? In some ways, as noted above, the work is not that different: "the core legal work remained the same" as that of a lawyer operating in one of the "traditional modes of public interest advocacy (impact litigation, legal services, lawyer as organizer). ${ }^{198}$ In the case of a broader campaign, however, the lawyers added value because they could serve as an intermediary between the rigid legal system and the organizers seeking to push boundaries; the legal work added a kind of

${ }^{192} I d$. at 1910.

${ }^{193}$ See id.

${ }^{194} I d$. at 1911.

${ }^{195}$ See id. at $1914-15$.

${ }^{196} I d$. at 1914 n.137.

${ }^{197}$ I intentionally note that the impact is only directly felt by lawyers. Of course, the added pressure imposed by ethical obligations as well as a hostile judge would indirectly impact the campaign, workers, and organizers, in that any bad outcomes experienced in the litigation would have an effect on the underlying cause as well.

198 See Ashar, supra note 121, at 1918. 
"legitimacy" to the organizers' broader advocacy efforts, but the organizers did not have to operate under the limitations of court rules. ${ }^{199}$ This also helped the organizers strategically, as they could "maintain distance from governmental and private entities," which allowed them to "remain oppositional and retain movement vitality." 200 The litigation itself, however, also furthered the "greater resistance agenda" of the campaign. ${ }^{201}$ The clinic's involvement in the campaign made it clear that direct participation in the legal system can be particularly powerful for immigrant workers because "the assertion of rights through litigation can, at least partly, compensate for [the workers'] lack of legal status as they attempt to assert countervailing power in their workplaces and communities." ${ }^{202}$ It also demonstrated that such advocacy serves to "strengthen[] the sense of membership in American communities and the solidarity of some of the immigrant workers." 203

The second case study is a chronicle of a more than two-decade long litigation strategy regarding the rights of day laborers in Los Angeles. ${ }^{204}$ The challenges mounted against antisolicitation ordinances ${ }^{205}$ were part of a broader campaign seeking to protect, promote, and enforce the rights of day laborers, with multiple key actors and organizations playing organizing and legal roles. In particular, the strategy revolved around "First Amendment challenges to ordinances passed and actively enforced throughout the region," with a goal of "abrogat[ing] (or modify[ing]) ordinances in cities that ... passed them and to deter their enactment in cities where they are under construction," the "ultimate legal objective" being "a definitive ruling on the merits in favor of solicitation." 206

The role of litigation in the overall day laborer campaign was not unlike that of the wage and hour case on behalf of restaurant workers in New York - it was meant to serve as one aspect of a broader campaign, as a way to complement an overall organizing strategy. ${ }^{207}$ While organizers mobilized

199 Id. at 1922.

${ }^{200} \mathrm{Id}$.

${ }^{201} I d$. at 1918.

202 Id. at 1921.

${ }^{203} I d$.

204 See generally Scott L. Cummings, Litigation at Work: Defending Day Labor in Los Angeles, 58 UCLA L. REV. 1617 (2011).

205 Antisolicitation ordinances "aim to regulate immigration indirectly," by "criminaliz[ing] conduct engaged in disproportionately by immigrant workers." Id. at 1620. Though the exact contours vary, which Cummings explains in detail, see id. at 1633-37, they generally target some aspect of the activity of soliciting work in public spaces, in order to drive away day laborers from the communities in question.

206 Id. at 1621.

207 See id. at 1639 (noting that one of the attorneys involved from the start "sought to advance a vision of community lawyering in which the lawsuit was complemented by efforts to build an organizing base"). 
workers and advocated for their position with local governmental officials, the ability to go to court - and, after the first victory in one of the cases, the ability to win in court - proved essential: "The organizing complemented the litigation, like 'carrot and stick,' showing cities that there was a high road toward cooperative solutions on day labor, but that movement lawyers could prevail on the legal merits if necessary." 208

The integration of lawyers and the litigation into the campaign was not always so neat, however. Some of this was simply based on a particular individual lawyer's approach to client- and organization-relations, with some attorneys placing more of an emphasis on the need to "relate to day laborers and value the contributions of organizers," which allowed them to build trust between themselves and the workers. ${ }^{209}$ However, there was also an overall tension between the core principles of the day laborer movement and the particular legal strategy employed by the lawyers. Specifically, relying on a First Amendment theory may have been a more "winnable" claim, both legally and also from a public-relations perspective_- "cast[ing] day laborers in their most favorable light: active, diligent, and contributing to the economic good by taking jobs no one else wanted"-but it aligned with the movement's goals less neatly than a discrimination claim would have. ${ }^{210}$ In choosing the free speech theory over a discrimination theory, the lawyers "obscure[ed] the real motivation of [the antisolicitation ordinances'] proponents: to eliminate immigrant workers from the street," and instead "made a choice to maximize the chances for success on the legal merits to advance the immediate movement goal (eliminating ordinances) rather than to make stronger claims that may have supported the immigrant rights movement's most ambitious agenda."211

Beyond the difficult tactical choice in claims, litigation also proved to be problematic because of its inherent risk. Given that the ultimate legal objective was to obtain a definitive legal ruling on day laborer rights, the stakes were high. A negative ruling from an appellate court carried with it the possibility of undoing years of strategic work - and an initial decision from the Ninth Circuit did just that. ${ }^{212}$ Fortunately, a rehearing of the case en banc resulted in a more favorable outcome, ${ }^{213}$ but the successful outcome does not

${ }^{208} I d$. at 1649. The organizers also referred to the high road approach, focused on making connections with local law enforcement officials and the business community, as a "human relations" model. See id.

${ }^{209} \mathrm{Id}$. at 1682.

${ }^{210} I d$. at 1685 .

${ }^{211} I d$.

${ }^{212}$ See id. at 1680 (noting that the "damage had been done," and that "[ $\left.\mathrm{t}\right]$ he decade-long path to a definitive ruling on the merits by the Ninth Circuit striking down antisolicitation ordinances had resulted in just the opposite").

213 At the time of publication of the case study, advocates were awaiting a ruling from 
change the fact that the very nature of the goal of the litigation carried with it an inherent - and sizeable - gamble on the part of the legal team.

Such a risk is not necessarily inherent to litigation as a tactic, however, but may instead say more about the underlying population whose rights are at issue. As Scott Cummings reflected at the close of his case study, when the Ninth Circuit case was still pending:

Despite the uncertain future of the day labor campaign, it is important to emphasize in conclusion that how we evaluate its outcome has to be framed in relation to the question: As opposed to what? What were the alternative avenues of preserving the right of day laborers to solicit work? Politically, they were weak - and continue to face significant challenges to building political power. If litigation does not ultimately "work" in this context, it seems likely that it reflects not the deficits of litigation per se, but the underlying political vulnerability of day laborers themselves. ${ }^{214}$

Similarly, the advocates involved in the movement, while crediting the role of litigation in the overall organizing strategy, did not hang their hat on the outcome of the case. Instead, they highlighted various other victories achieved along the way: making connections to political leaders, building coalitions to the business community, organizing and building relationships with workers, and overall building the power of the community of day laborers whose rights the movement was intended to advance. ${ }^{215}$

In the end, like the restaurant workers, the day laborer study tells the story of litigation serving as one prong of a multi-faceted strategy to support worker organizing, though simultaneously illustrating that a broader legal goal resulted in greater risk and thus potential downside to the movement. But even in smaller-scale litigation, the stakes can still be quite significant: a victory can give a meaningful boost to organizing efforts, whereas a loss in court or the use of chilling tactics by employers or defense counsel during litigation can impede movement goals by dissuading workers from coming

the Ninth Circuit Court of Appeals as to the constitutionality of an antisolicitation ordinance in Redondo Beach, CA; a panel had previously upheld the ordinance, and the plaintiffs filed a petition for rehearing en banc, and were awaiting the decision from the full panel of judges. See id. at 1680-81. In September 2011, the Ninth Circuit issued its decision, holding that the ordinance was facially unconstitutional. See Comite de Jornaleros de Redondo Beach v. City of Redondo Beach, 657 F.3d 936, 940 (9th Cir. 2011) (en banc); see also Press Release, MALDEF, Ninth Circuit Court Ruling Sets Positive Precedent for Day Laborer Rights (Sept. 16, 2011), http://www.maldef.org/news/releases/ninthcircuitruling_dlr/.

${ }^{214}$ Cummings, supra note 204, at 1699. For a more in depth analysis challenging the view that lawyers and a legal strategy can negatively impact social movements, see Cummings, supra note 177.

215 See Cummings, supra note 204, at 1687-90. 
forward about legal violations or engaging in activism around their rights.

There are several other lessons about the role of litigation that can be drawn from these two case studies. The first is that, in many ways, the core work of the lawyers is not that dissimilar from what lawyers in other settings may do. They research and strategize about legal claims, they file lawsuits and interface with judges and defendants and their counsel while the lawsuit progresses, and they either settle cases along the way or pin their hopes on a final decision from a court. Beyond this work, however, the case studies spotlight how lawyers engage with the workers and organizers who are at the core of the movement. The lawyers are not separate from the workers and the organizers, but instead occupy their own role and function within the movement. This engagement further serves the important goal of building trust between the lawyers and the workers and organizers, which will prove integral to any successful legal representation. Finally, given their unique position as advocates within the legal system, lawyers and the litigation they pursue on behalf of their clients give a particular kind of legitimacy and recognition to the movement and its goals. Although the lawyers are not the protagonists of the story, ${ }^{216}$ their work helps to give a particular resonance to the story and to the individuals who are.

\section{B. Voice and Empowerment in Litigation}

While there is some organizing of guestworkers both in the United States $^{217}$ and their home countries, ${ }^{218}$ these examples are limited, particularly among H-2A workers. Given the inherent hurdles that advocates face in reaching $\mathrm{H}-2 \mathrm{~A}$ workers, ${ }^{219}$ it is understandable why such communities are

216 See Gordon, supra note 120.

217 The organizing work in the United States is largely focused on guestworkers more generally, rather than H-2A workers specifically. See, e.g., Lee, supra note 62, at 43 (describing role of the National Guest Worker Alliance in organizing guestworkers, H-2B workers); see also Chuang, supra note 175, at 323-24 (2013) (noting National Guest Worker Alliance role in organizing J-1 visa holders and possible expansion of organizing efforts in that field); but see Eli Francovich, Strikes, work stoppages in Washington fields indicative of changing agriculture labor environment, THE SPOKESMAN REVIEW (Spokane, Wash.), Nov. 5, 2017, http://www.spokesman.com/stories/2017/nov/05/strikes-work-stoppages-inwashington-fields-indica/\#/0 (documenting successful strike H-2A workers in Quincy, Washington).

218 For example, Centro de los Derechos del Migrante, an organization focused on empowering Mexican migrants who work in the United States, spearheads an initiative known as Contratados, an online portal where workers can share reviews and experiences with specific recruiters so as to enhance the knowledge of and transparency for other migrant workers going forward. See CENTRO DE LOS DERECHOS DEL MiGRANTE, Contratados, http://www.cdmigrante.org/contratados/ (last visited August 1, 2017).

${ }^{219}$ See supra section II(B)(1). 
difficult to mobilize. As a result, it is often the case that, when litigation on behalf of H-2A workers is undertaken, it is conducted in isolation, without the organizing activity that permeates the community lawyering models described above. Nevertheless, it is possible to work towards the goals of community lawyers and have litigation serve as a tool for empowerment and worker voice even in the absence of parallel organizing efforts.

The way in which the process of litigation itself can serve as a tool for client voice and empowerment, however, is under-explored. For example, one relatively recent article draws on procedural justice theories ${ }^{220}$ to consider civil litigation as a tool for voice, but does so only briefly, as part of a broader discussion of multiple legal doctrines, and without regard to variations in approaches and experiences depending on the client bases being served. $^{221}$ General considerations of a litigant's subjective feelings of fairness, in keeping with a procedural justice analysis, ${ }^{222}$ may be a useful tool for evaluating an H-2A worker's interaction with the legal system overall: with would-be plaintiffs who are outsiders to such a significant degree, even minimal increases in a sense of "fairness" will likely be proportionally substantial. However, I seek to move beyond generalities and provide a more context-specific approach. To that end, the following discussion will take particular care to highlight the ways in which expressing voice can be complicated by the fact that a litigant is an $\mathrm{H}-2 \mathrm{~A}$ worker. At the same time, I also underscore the additional value that such moments can have because of the worker's status.

Below, I focus on what I call four "moments" in the life of a civil lawsuit in particular: the decision to file a lawsuit, the filing of the complaint, discovery, and trial. ${ }^{223}$ Litigation is obviously unpredictable and it goes

\footnotetext{
${ }^{220}$ Generally situated within the field of social psychology, procedural justice studies tend to examine the link between an individual's participation in the legal process and that individual's sense of satisfaction with the process. See, e.g., Rebecca Hollander-Blumoff, The Psychology of Procedural Justice in the Federal Courts, 63 HASTINGS L.J. 127, 132 (2011) ("Over thirty years ago, psychologists began to research legal systems in an effort to increase compliance with judicial decisions. In particular, researchers focused on what kinds of processes would seem most fair to disputants and would lead to increased acceptance of and adherence to judicial decisions. This research provided robust empirical evidence that individuals care deeply about the fairness of the process by which decisions are made, apart from considerations about the outcome of the decision."). Often referred to as "voice, process control, or [the] opportunity to be heard," $i d$. at 142, scholars writing about procedural justice issues focus not on winners and losers in the legal system, but rather the degree to which all participants leave a legal interaction feeling that they have had a fair experience, $i d$. at 145 .

${ }^{221}$ See id. at 149-75.

222 See supra note 220.

${ }^{223}$ Settlement - rather than trial - is more likely to be the closing "moment" in a lawsuit. See infra note 257 (discussing decreasing rate of trials in civil cases as well as other means by which civil cases are resolved). Because of the opportunity settlement provides for
} 
without saying that not all of these moments will occur in any given case that gets filed in court. And even if they do, the nature of how a case may unfold at each step can vary depending on numerous factors, including the location of the litigants, the collaborative nature of opposing counsel (or lack thereof), and the willingness of the court to adapt to the unique demands of a lawsuit involving H-2A worker plaintiffs. I attempt to address these nuances at each phase in the following discussion.

\section{Taking Legal Action}

The first step in the life of a civil lawsuit occurs before it even existsthe decision to file a case in the first place. Indeed, this moment is what has drawn much of the focus of the client-centered lawyering literature. ${ }^{224}$ With $\mathrm{H}-2 \mathrm{~A}$ workers as clients, however, this decision and the related discussions between lawyer and client should be approached with extra care.

One anecdote from the day laborer case study provides a useful analogue for the present discussion. As an attorney and organizer discussed the possibility of filing a lawsuit against the city of Baldwin Park with affected day laborers, the workers responded with a host of questions, including: "Will you be the lawyer? Who will be the judge? Will we get arrested? How long will it take?",225 While the questions are clearly tailored to the enforcement activity experienced by those specific workers, the "very

forward-looking remedies, however, I have chosen to discuss settlement in the section that focuses on opportunities for voice beyond a lawsuit itself. See infra section III(C)(1).

${ }^{224}$ Such a focus has often been to the exclusion of other important decisionmaking moments in the course of a lawsuit. For example, Binny Miller has noted:

With few exceptions, client-centered writers analyze the decisions facing the client in generic terms, without distinguishing the type of decision at stake. When they discuss the context of a decision specifically, the most active arena of client decisionmaking appears to be in the area of legal process, either in initiating legal procedures - by filing a lawsuit or an appeal or invoking an informal mechanism, for example - or disposing of a case through settlement or trial. This focus on process implies that other kinds of decisions are relegated to lawyers and thus are excluded from the lawyer-client dialogue.

Miller, supra note 15, at 505; see also Dinerstein, supra note 15, at 589-90 (noting origin of client-centered model as focusing on decision between litigating, settling, or doing nothing).

225 Cummings, supra note 204, at 1672. In addition to Baldwin Park, the case study provides other examples of pre-filing discussions with workers. See id. at 1661 (describing a lawsuit in Redondo Beach as being viewed as "the only viable course of action" by the workers after law enforcement raids), 1667 (noting detailed discussions between lawyers and day laborers in Lake Forest about filing suit, including concerns regarding retaliation and confidentiality, and ultimate decision to do so because "the workers 'collectively decided it was worth the risk"'). 
pragmatic",226 inquiries nevertheless are illustrative of questions I and other advocates have fielded from $\mathrm{H}-2 \mathrm{~A}$ workers. Broadly speaking, they fall into two categories: questions concerning the process of filing a lawsuit and those concerning the consequences, both potential and perceived, of doing so.

With respect to the process, given H-2A workers' likely unfamiliarity with the legal system in the United States, ${ }^{227}$ the entire idea of a lawsuit can be a black box. As a result, attorneys seeking to be client-centered and to give voice to their clients by representing them in civil litigation should be prepared to answer such inquiries in a comprehensive and respectful way. Explaining what a lawsuit is, at its most fundamental, is essential. By way of example, I have typically offered clients an overview along the following lines:

Filing a lawsuit means that we will prepare a formal document saying what happened to you and what laws were broken as a result of that. We will take that document and file it with a court. We will then give your employer a copy, to notify him that he has been sued. He will then have the chance to respond. From there, the case can proceed through a long process of something known as discovery ${ }^{228}$ before potentially getting to something that is called a trial. A trial is when everyone will go to the courthouse where we filed your case and sit in a room in front of a judge, and maybe a group of ordinary people (the jury), ${ }^{229}$ who will hear from witnesses and look at the other evidence, like documents. At the end, either the judge or the jury (if there is one) will decide who wins. But, most cases don't get to that point, and instead come to a resolution with a mutual agreement between both sides, generally with a payment from the employer to you and the other workers who filed the case in exchange for dropping the case. Unfortunately, I cannot predict when or if the case will resolve in that way. I only know that most cases do end that way. So, while that is likely to happen, we have to assume that we are going all the way to trial until and unless we have a signed agreement that ends the case and your claims.

On one level, this is a very general overview, omitting the twists and turns and painstaking detail of litigation. But on another level, it is a detailed

${ }^{226} I d$. at 1672.

${ }^{227}$ See supra section II(B)(1)(a).

${ }^{228}$ Additional details on describing the discovery process are outlined in a subsequent section. See infra section III(B)(3).

${ }^{229}$ In other words, this depends on whether there has been or will be a jury demand in the case, or whether it will proceed as a bench trial. 
explanation of the general process of a civil lawsuit, covering what is likely to happen over the course of a case, and trying - perhaps unsatisfactorilyto answer one of the questions posed by the day laborers cited above: "how long will it take?" For attorneys or for relatively legally sophisticated clients, these steps are generally assumed and not often broken down in such a basic way. The same is likely true of the overarching uncertainty of the process. But for H-2A workers, who are not familiar with the U.S. legal system and who may not have ever had any interaction with any legal system, here or at home, this is an essential roadmap that allows them to approach the decision in a much more informed manner, having a better, more realistic understanding of what this process may entail.

Beyond the process, workers may also have questions about the risks they face by deciding to file a lawsuit. Given the unique risks of retaliation they face because of their visa status, ${ }^{230} \mathrm{H}-2 \mathrm{~A}$ workers are likely to have questions about what may happen to them if they decide to sue their employer or former employer. They may want to know if filing a lawsuit will impact their ability to get another visa in the future, or they may ask if other employers - or their current employer, assuming it is not the defendant-will know about the lawsuit. While the answers will certainly depend upon the particularities of a given worker's situation, one guiding principle in responding to such inquiries is the importance of recognizing the difference between the letter of the law and the practical reality on the ground. For example, being a plaintiff in a lawsuit may not be a legal bar to getting an $\mathrm{H}$ $2 \mathrm{~A}$ visa in the future - there is no blacklist of civil plaintiffs maintained by U.S. government officials along these lines-but it may be a practical problem if the worker knows of no other potential routes to obtaining an $\mathrm{H}$ $2 \mathrm{~A}$ visa other than the employer who is now being named as a defendant and is therefore unlikely to want to hire the same $\mathrm{H}-2 \mathrm{~A}$ worker again. Moreover, an employer's decision not to rehire the same $\mathrm{H}-2 \mathrm{~A}$ worker may be explicitly retaliatory in its motivation, but as a worker with a temporary visa with no ongoing right to return or to obtain another visa in the future, an H-2A worker seeking to make a legal claim out of the lack of rehire would likely fail. In short, the answers to the questions may not always be "good"- they may likely be enough to dissuade a worker from filing suit. Nevertheless, the important lesson for attorneys adopting a client-centered approach in this process is that, without providing a response based on both the law and the on-the-ground reality, the attorney fails to fully acknowledge a client's situation. Because, for workers who have already experienced such blatant and regular violations of their rights, it is too often the case that such rules by which their employers are supposed to abide can be worth as much as the

\footnotetext{
${ }^{230}$ See supra section $\mathrm{II}(\mathrm{B})(1)(\mathrm{c})$.
} 
paper on which they are written.

It would be difficult to provide an exhaustive list of potential questions and suggested answers for attorneys of $\mathrm{H}-2 \mathrm{~A}$ workers to use as a reference - indeed, every case presents a unique set of circumstances, actors, and risks. The above discussion does not aim to do so. Rather, I simply argue that an attorney following client-centered principles should recognize that there may be a gap in understanding with $\mathrm{H}-2 \mathrm{~A}$ worker clients, even more than that which exists with U.S. worker clients, and be prepared to address such issues. Because, if a lawsuit is to serve as a vehicle for worker voice and empowerment, it is critical that an $\mathrm{H}-2 \mathrm{~A}$ worker first understand the context in which his voice is being heard, and it is the attorney's job to ensure that the worker has such an understanding.

\section{Filing the Complaint}

The filing of a complaint represents the first moment in the course of a lawsuit in which an H-2A worker asserts himself in a public manner and is able to upend the previous dynamic that existed between himself, his employer, and the U.S. government more broadly. Outsiders from the beginning, H-2A workers now stand to take the power back from their employers and bring it to their side. ${ }^{231}$ In so doing, an H-2A worker plaintiff finds voice in two very important ways: by no longer being nameless and by being able to tell the story of what has happened to him.

As to the first point, I have already discussed how H-2A workers proceed through most of the $\mathrm{H}-2 \mathrm{~A}$ application process as an unnamed worker. ${ }^{232}$ Such anonymity often continues throughout their time in the United States. Due to language barriers, workers rarely communicate directly with their employers, instead using supervisors or other sufficiently bilingual individuals to assist with interpretation among the parties. Thus, the employers are unlikely to know specific workers by name. On the contrary, it is not uncommon for employers to simply refer to their workers

${ }^{231}$ Stephen Pepper has noted that, despite a civil lawsuit not involving the government as one of the parties and thus not appearing to "pit[] 'the state,' with all its power, against an individual," as the criminal system does, a civil lawsuit does still involve the power of the state on one side:

[T] he very point of civil litigation is to allow the private plaintiff to gain the power of "the state" to enforce her claim against the defendant, thus removing the need for, or utility of, acquiring private police or armies to enforce claims. Civil litigation is a contest over which side is to have the vast power of "the state" on its side in a dispute.

Stephen L. Pepper, The Lawyer's Amoral Ethical Role: A Defense, Some Problems, and Some Possibilities, 1986 AM. B. Found. RES. J. 613, 623.

232 See supra note 55 and accompanying text. 
generically—and, arguably, disparagingly — as "the Mexicans" or a similar term. ${ }^{233}$ When a worker files a complaint in court against his employer, on the contrary, his name appears at the top of the complaint, in clear and unequivocal terms. ${ }^{234}$ For perhaps the first time in the entirety of his interactions with his employer, the worker now goes by his actual name.

In addition to empowerment through identification, the filing of the complaint also provides a worker with the opportunity to tell his story for the first time, outlining what happened to him in order to support the legal claims brought against the employer. ${ }^{235}$ While it is possible to file a complaint that focuses solely on the specific facts giving rise to the worker's claims - for example, simply outlining the hours he worked and pay he received in the context of a wage and hour claim - and not delve into much else, such a strategy fails to paint a complete picture of the worker and his situation. By taking a broader view of the purpose of the complaint, an advocate can be more faithful to the worker's experience, giving it voice, and thereby assist in conveying the worker's story, and the story of the H-2A program more broadly, to the opposing party and the court itself. ${ }^{236}$ Thus, for example, the complaint filed on behalf of the Kentucky tobacco workers referenced at the start of this article contained an overview of the $\mathrm{H}-2 \mathrm{~A}$ program and the employer's resulting obligations to the workers; the targeted recruitment of the workers in Mexico; the various pre-employment expenses and debts the workers incurred; the employer's pay practices and the resulting underpayment of the workers; the deplorable state of worker housing; and the ongoing unlawful payments the workers were required to pay, all against a repeated stream of threats to cancel their visas if they refused to comply. ${ }^{237}$ Such a comprehensive narrative painted a clearer picture of what had

\footnotetext{
${ }^{233}$ See, e.g., supra note $60 ; c f$. Holley, supra note 19 , at 612 (recounting statement by a legislator from western Kentucky describing immigrants as "your Mexicans").

${ }^{234}$ There are instances in which this may not happen, for example, if a worker is attempting to proceed as a John Doe plaintiff as a precautionary measure against potential retaliation against himself or his family. There may also be cases such as class actions where not all workers who may ultimately recover damages for mistreatment are named on the complaint. However, in the vast majority of cases, workers do file as named plaintiffs, their names appearing on the court pleadings.

235 See Hollander-Blumoff, supra note 240, at 152 (analyzing the way in which the pleading process allows for a plaintiff to express his or her voice).

236 Sharing the worker's story, particularly within the judicial system, would be particularly important because, as commentators have noted, federal courts tend to be venues dominated by corporate, rather than individual, parties. See, e.g., id. at 147-48 (discussing dominance of corporate parties in federal court litigation). As such, telling the story of an ultimate outsider litigant - the H-2A worker - will prove to be a strong counter-narrative to the normal stories that such courts would hear.

${ }^{237}$ See Complaint, Cruz-Cruz v. McKenzie Farms, No. 05:15-cv-157 (E.D. Ky. May 28, 2015).
} 
happened, providing necessary context for the trafficking claims brought in that case, ${ }^{238}$ as well as garnering enough interest from a reporter to lead to an in-depth story published in the local paper a few weeks later. ${ }^{239}$

While powerful because of the statement that it sends, however, the degree to which the complaint represents a worker's voice is muted by the reality that it serves as a specific legal document that must be in keeping with pleadings standards and other legal rules. ${ }^{240}$ Thus, the worker's story is there, but amidst statements regarding the jurisdiction of the court to hear the case, or citations to certain statutes that the employer allegedly violated. More generally, the complaint is in English - often not understood by workersand so there is the more literal translation of having to tell the worker's story in a language in which it did not originate. In other words, while the complaint does represent the worker's first moment to use his voice in litigation, in reality it is more of an indirect voice, telling the worker's story, but in a "sterilized" way, ${ }^{241}$ or in the "dialect" of the legal system. ${ }^{242}$ Nevertheless, the drafting and filing of the complaint presents the opportunity to paint a picture and set the (public) stage, and advocates endeavoring to be client-centered can find methods by which to incorporate the voices and experiences of clients amidst the other legally-required or preferred language.

\footnotetext{
${ }^{238}$ Because forced labor claims require demonstrating something a bit more subjectivei.e., that the plaintiffs were threatened with "serious harm," or that the defendant "threatened abuse of law or legal process," see, e.g., id. at III 144-53-a complete picture of the plaintiff's situation at the time of the defendant's actions makes it necessary to understand the plaintiff's state of mind.

${ }^{239}$ See supra note 1.

${ }^{240}$ Rebecca Hollander-Blumoff has also noted that the heightened pleading standards imposed by the two Supreme Court decisions of Bell Atlantic Corp. v. Twombly, 550 U.S. 544 (2007), and Aschroft v. Iqbal, 556 U.S. 662 (2009), may have a negative meta effect on voice:

From the plaintiff's perspective, the restrictions on pleading - even though they require a pleader to say more - may decrease perceptions of procedural justice. Pleaders often are not fully aware of the facts in a dispute, especially the facts most supportive of their allegations. Although requiring plaintiffs to say more about these facts may look, at first blush, like an opportunity to increase participation, in fact this requirement dampens participation because it raises the bar to have one's case before the court at all. By raising this level, these two decisions will cause some cases not to be heard, thereby completely depriving potential plaintiffs of their voice.

Hollander-Blumoff, supra note 240, at 153.

241 See Richard Delgado, Storytelling for Oppositionists and Others: A Plea for Narrative, 87 MICH. L. REV. 2411, 2428 (1989) (arguing that fitting facts into the style required by a court complaint "sterilize[s] them," and "legitimate[s] the current social order").

242 See supra note 111.
} 


\section{Discovery}

Once a civil lawsuit has proceeded beyond the initial pleading stages, the parties then turn to the multi-faceted process known as discovery. At its core, discovery is about the exchange of information, thus providing litigants with an opportunity to share their story with the other side. ${ }^{243}$ Similarly, discovery also evens the playing field between parties who may possess different amounts of information, and, therefore, power. ${ }^{244}$ As such, it provides a useful opportunity for enhancing the voice of $\mathrm{H}-2 \mathrm{~A}$ worker litigants.

Discovery itself has numerous aspects, but the two that are important from the perspective of client voice are responding to interrogatories and depositions. ${ }^{245}$ Generally speaking, both interrogatory responses and depositions provide the opportunity, albeit not unlimited, for an H-2A worker plaintiff to respond to questions from the opposing party and provide

${ }^{243}$ See, e.g., Hollander-Blumoff, supra note 240, at 154-55 (noting that discovery "is a mechanism that is expressly designed to enable participation and voice" and that it "provides both parties with the opportunity for meaningful participation by allowing them access to information that will form the basis for their presentation to the court"). In a similar vein, I have taken to use the term intercambio de información-literally, the "exchange of information" - to explain the idea of discovery to Spanish-speaking clients.

244 See John S. Beckerman, Confronting Discovery's Fatal Flaws, 84 MinN. L. REV. 505,514 (2000) (describing the advent of the Federal Rules of Civil Procedure and its implementation of the discovery process as a method of "eliminating systematic unfairness resulting from disparities of wealth and power by prescribing means by which less powerful litigants could obtain the information necessary to prove their claims").

${ }^{245}$ In particular, the third in the main trio of discovery tools is requests for production of documents. See FED. R. CIV. P. 34. Depending on the documents, it is possible that an H$2 \mathrm{~A}$ worker's voice would be revealed in this method of providing information to the opposing party; for example, documents subject to production could include past correspondence or other writings, or even audio or video recordings that would more literally capture the worker's voice. See id. 34(a)(1)(A) (including "electronically stored information" among items that can be requested by a party, which is explicitly intended to cover "writings, drawings, ... photographs, sound recordings, images, and other data or data compilations" that are "stored in any medium from which information can be obtained either directly or, if necessary, after translation by the responding party into a reasonably usable form"). However, I am less interested in this potential expression of voice because it, unlike responding to interrogatories and providing deposition testimony, is not (generally) the expression of voice after a lawsuit has been filed - in other words, with the intention of remedying a violation of the worker's rights. For this reason, I focus less on this possible implication of past voice, and instead focus on the more direct implication of voice in the present that is brought about through interrogatory responses and depositions. Similarly, I acknowledge that there are a whole other host of tools employed by litigators during discovery that I have not even mentioned, mostly because they are not seeking discovery from the other party directly, and thus are even less relevant to the focus of this article. These would include, for example, subpoenas for the production of documents served on third parties, see id. 45, and requests for entry and inspection of land, see id. 34(a)(2). 
information in his or her own voice. ${ }^{246}$

In the case of interrogatories, the degree of voice is slightly attenuated. On the one hand, unlike a complaint drafted by attorneys, the responses do, literally, belong to the worker. ${ }^{247}$ However, because they are written and because they are provided in response to specific questions posed by the opposing party, there is a certain degree of control over voice that is lost. The opposing party frames the issues, and thus the worker may not be telling his story in the way the he may most desire. Moreover, because interrogatory responses are provided in writing, they must be in English, necessitating both a literal and figurative translation from the worker's original answer. Both of these factors equate to a certain loss of voice during this process. Despite this inevitability, a lawyer seeking to emphasize the client's perspective can lessen such effects by ensuring that the client's written response uses terminology and phrasing that captures the client's voice, as opposed to mimicking the legalese that the opposing party is likely using in the interrogatories themselves. ${ }^{248}$

Depositions, on the other hand, provide a worker with a greater degree of participation, as well as literal moments of voice and expression. Because of this, a lawyer seeking to embody client-centered principles should put the deposition in context for the $\mathrm{H}-2 \mathrm{~A}$ client. Much like a lawsuit as a whole, a deposition is also an unknown setting into which a worker is entering. Thus an attorney should not simply dive into a standard deposition preparation, reviewing the facts giving rise to the worker's claims, but should instead take the time to explain what a deposition is, both as a technical matter and as an extended interpersonal interaction. For example, I have often explained a deposition as a formal one-on-one interview under oath, conducted by the attorney for the other side, and with a court reporter taking notes of what everyone says. In addition, I also believe it is important to explain to clients some of the dynamics and roles that should be expected during such an event.

\footnotetext{
${ }^{246}$ Lucie White similarly recognized that affidavits submitted by clients in the course of a case she litigated represented the "one aspect" of the case that "gave the clients something of a voice." White, supra note 111, at 541 n.26. However, because affidavits are prepared by an individual's own attorney and are generally not in response to a very specific line of questioning, unlike both interrogatories and depositions, the analysis of client voice in such a setting would more likely align with that of client testimony at trial, see infra section III(B)(4), as opposed to the discovery process.

247 As an individual, the worker would be the "responding party," and would have to answer an interrogatory "under oath" and sign the answers. See id. 33(b)(1)(A), (b)(3), (b)(5).

248 The problem of legal terminology and client misunderstanding can also occur in depositions. See infra note 254. With interrogatories, however, defense counsel may use stock interrogatories, particularly if they regularly represent employers or are appointed by an employer's insurance company to defend the employer in the lawsuit. The risk of legalese is, therefore, more common — or, at least, less immediately and easily remedied — when it is in a written medium, as opposed to in an interpersonal interaction.
} 
Specifically, clients should be aware that their responsibility is simply to listen to the questions and answer by telling the truth. Anything else-if opposing counsel behaves disrespectfully, or asks inappropriate questionsfalls within the lawyer's responsibilities. Even more generally, it is critical to situate the interactions within the broader context of the case. Specifically, I have explained to clients to expect that, when we arrive to the deposition, I will be polite with the other attorney, shaking their hand and engaging in small-talk. Without a prior explanation, such an interaction may seem jarring to the client, who suddenly sees his own attorney fraternizing with the opposition. A preemptive warning that this is simply part of the process and not any substantive betrayal or disrespect of the client is, therefore, important to set the client's expectations for the event.

Turning to the substance of the deposition, the moment offers a chance for worker voice because it is, quite literally, a setting in which the worker provides verbal testimony in response to questioning by the opposing party's attorney. ${ }^{249} \mathrm{He}$ thus speaks and tells his story in his own language, using his own words. And, importantly, when using these words, an H-2A worker litigant is generally (absent any misconduct by opposing counsel) afforded respect and dignity that he might not have otherwise seen during his time as a worker, being given the floor to speak in front of individuals who are usually considered more powerful and thus the ones on the receiving end of such respect-multiple attorneys, court personnel, perhaps corporate representatives, and others that may be present during deposition testimony.

In spite of this literal use of voice, there are some important caveats to note about the power of deposition testimony. The first is that, in most cases, the worker testifies with the aid of an interpreter, and thus there is a certain degree of voice that is lost in that translation from one language to another, just as with interrogatories. This loss may be more than figurativethere is also the risk of inaccurate translations, and meaning that gets lost with terminology or sayings that exist in one language but not the other (or figures of speech or words used by the worker that may be regional or industryspecific and thus not known to the interpreter). To compound the risk of error, the norm in most cases is for deposition testimony to be transcribed by a court reporter, with the only record of the worker's testimony being the English language answer, spoken by the interpreter.

An illustration of one of my experiences with such an interpreter error and the substantive confusion and problems it may cause may be useful. Some of my clients have used the Spanish term contratados in depositions to refer to H-2A workers. This is a common term among H-2A workers, and literally means "contracted," or "the contracted ones," i.e., the workers who

\footnotetext{
${ }^{249}$ There is an exception: the Federal Rules do contemplate the possibility of deposing a witness, including a party, by written question. See FED. R. CIV. P. 31.
} 
are contracted, or on $\mathrm{H}-2 \mathrm{~A}$ visas. This is a colloquial term, and thus likely not immediately understood by interpreters who may speak more formal Spanish. In the course of a deposition, a client used this term, and the interpreter translated it as "contractor," likely due to a lack of familiarity with the term. ${ }^{250}$ Given that the translation into English was essentially the opposite of what the client was saying in Spanish - the supervisor, as opposed to the worker-I and my colleagues interjected, stating that the witness had said contratados, and likely meant "H-2A workers." As a result, the interpreter checked with the witness, confirmed this understanding, corrected the mistranslation, and employed the correct terminology going forward. Had that correction not taken place, the transcript would have been confusing and, more fundamentally, incorrect. An additional method to guard against the possible lasting effect of such errors, which we had not done in that case, would be to record the deposition on video or in audio format, thereby preserving the actual words spoken by the testifying worker. ${ }^{251}$ This strategy has the additional benefit of preserving the original testimony of the worker in the event he is not able to appear for trial. ${ }^{252}$

The final caveat, to which I alluded briefly in the context of interrogatories, is the larger issue of who defines the contours of this testimony. A deposition is most often taken by the opposing party, and it is therefore the opposing party who generally sets the line of questioning and focus of the deposition. ${ }^{253}$ At times, this may involve asking about information that a worker may consider irrelevant or even sensitive-for example, questions about his family or employment. But, it may also include open-ended questions seeking to get as much information as possible, thereby

${ }^{250} \mathrm{H}-2 \mathrm{~A}$ workers generally use the term contratista to refer to the "contractor," usually meaning the supervisor or recruiter, depending on the circumstances. Because both words derive from the verb contratar, to contract or to hire, and because the English term "contractor" is used much more frequently than the idea of someone being a "contracted worker," perhaps the interpreter simply assumed the worker meant contractor, rather than the more literal (and colloquial) term he intended.

${ }^{251}$ This should be done in addition to, and not in place of, correcting errors on the record. If the errors are not corrected, the confusion would still remain in the formal transcript, which could be used as an exhibit in court pleadings, not to mention in the room during the remainder of the deposition itself.

${ }^{252}$ Depositions, whether reading the written transcript into the record or playing a recording of the deposition (if it was recorded), may be introduced at trial in the event a worker is unable to appear at trial. See FED. R. CIV. P. 32(a)(4) (providing for circumstances under which a party may use the deposition of an unavailable witness, including a party to the case, at trial). For additional discussion of difficulties in travel to the United States that would preclude a worker from appearing in person at trial, see infra note 258.

${ }^{253}$ There would be exceptions to this general rule, however. For example, a lawyer may seek to depose his or her own client in order to preserve testimony for trial in the event the client is unable to appear in person for trial. 
getting the worker to say as much as possible, about the facts underlying the worker's claims. The degree to which this bears out in practice can vary by case and by attorney, ${ }^{254}$ of course, but the fundamental point is that, at the end of the day, it is opposing counsel's time and deposition, and they are the ones who decide how to spend it.

It is important to acknowledge that a worker's own attorney may also have a limiting effect on the worker's voice. Specifically, an attorney may seek to strategically restrict the worker's testimony, for example, in counseling the worker against testifying against privileged matters or other matters that may be beyond the scope of discovery. ${ }^{255}$ From the perspective of the worker's attorney, this is done in the worker's best interest, to further his claims and not risk opening the door into irrelevant topics or lines of questioning that may be intrusive or even harassing. With that in mind, it is possible - if not likely — that a worker may view his attorney's advice to limit his voice in this regard as supportive of his experiences and his concerns, particularly if the attorney takes care to fully explain to her client the reasoning behind why this is the position she is taking and the justification for the worker not being required to talk about sensitive matters. Nevertheless, it is worth considering the degree to which this intervention by a lawyer might alter what would otherwise be a worker's sole choice of whether or not to speak about certain matters.

In sum, discovery certainly provides an opportunity for an $\mathrm{H}-2 \mathrm{~A}$ worker to express himself in ways that he would have not yet been able to do, at least in the course of litigation. He is able to use his own words, and is not as constrained by legal technicalities as in the complaint, for example. At the same time, a worker is not always able to define the contours of that voice. As Jean Koh Peters has recognized, "poor people are asked to both divulge more information and to limit the stories they are allowed to tell."256 Attorneys for $\mathrm{H}-2 \mathrm{~A}$ workers need to be aware of the ways in which not only opposing counsel, but they, also, have this effect on their client's voice. Such actions are not inherently problematic, but attorneys should attempt to take such steps in keeping with the worker's own desires and interests - and to be sure they are aware of the worker's preferences by maintaining an open

${ }^{254}$ In particular, counsel who are accustomed to deposing relatively sophisticated litigants or witnesses may naturally fall into a questioning style that would not be readily comprehensible to an average H-2A worker. For example, asking a worker what facts he knows to support his "claims" may not make any sense to the worker, while taking a step back and asking questions with less reliance on legal jargon is likely to be a more successful method of gathering information.

${ }^{255}$ The discoverability of a plaintiff's immigration status is often a disputed area in litigation involving immigrant or migrant workers. See, e.g., Lee, supra note 93, at 1075-76.

256 Jean Koh Peters, Habit, Story, Delight: Essential Tools for the Public Service Advocate, 7 WASH. U. J. L. \& POL’Y 17, 24 (2001). 
channel of communication between attorney and client - in order to amplify the stories that the workers themselves seek to tell.

4. Trial

Moving on from discovery, I will now examine the opportunities for worker voice at trial. ${ }^{257}$ In many ways, the opportunities for voice at trial are similar to the opportunities for voice at depositions. A worker is generally able to testify using his own words, in his own language, and therefore tell his story relatively directly, albeit largely within the constraints also discussed above (interpretation from his native language, most importantly). However, there are two important differences between voice at a deposition and voice at trial: the opportunity that trial presents to testify in-person in a court, and a change in who controls and defines the contours of the testimony.

Testifying in person at trial, barring any extenuating circumstances that would prevent an in-person appearance, ${ }^{258}$ is a particularly powerful

${ }^{257}$ Civil trials, particularly in federal court, are increasingly uncommon. See, e.g., John H. Langbein, The Disappearance of Civil Trial in the United States, 122 YALE L.J. 522, 524 (2012) (noting that, by 2002, $1.8 \%$ of civil cases filed in federal court went to trial); see also Stephen Susman, Civil Jury Trials Are Fast Becoming Extinct, THE HARVARD L. REC., Apr. 25, 2016, http://hlrecord.org/2016/04/civil-jury-trials-are-fast-becoming-extinct/ (summarizing decline in federal trials and noting that steep decline coincides with Supreme Court decisions in 1986 establishing new summary judgment legal standards). I therefore focus a good deal on the settlement of claims as a vehicle for client empowerment, and discuss this in a subsequent section. See infra section III(C)(1). Moreover, there are other methods by which civil cases reach a resolution other than going to trial and via a settlement. For example, there is the possibility that a worker loses on the merits through some decision by the court before trial, either dismissing the claims or granting summary judgment in favor of the defendant. (Rarer still, a court may grant summary judgment in favor of the plaintiff, as well.) While I acknowledge that is a possibility, there is no real role for the worker in those situations, given that they are usually decided on written pleadings submitted by the parties. Because of my interest in worker voice in litigation, I choose to focus the discussion on the two modes in which the parties can play an active role in resolving the claims, trial and settlement.

${ }^{258}$ Generally speaking, the issue of worker presence in the United States is one of the most significant logistical issues - and, potentially, the most significant dispute among the parties - during the course of litigation. Counsel for H-2A workers regularly encounter this issue because the workers are generally not present in the United States, given that they are migratory workers, and options for workers to come to the United States to give in-person testimony are limited. Specifically, a migrant worker from Mexico or Central America does not have the automatic right to travel to and from the United States, as such countries are not part of the Visa Waiver Program. See BurEau OF CONSUlar AFFAIRS, U.S. DEP'T OF STATE, Visa Waiver Program, https://travel.state.gov/content/visas/en/visit/visa-waiverprogram.html (last visited August 24, 2017). A worker may therefore attempt to secure a visitor (B-1 or B-2) visa in order to travel into the United States, but migrant workers would likely face difficulty establishing that they lack "immigrant intent," in other words, that they 
moment for amplifying a worker's voice in the course of litigation. The worker has the floor, just as he does at a deposition, but the circumstances are heightened even further-he is in a courtroom, in front of a judge and a jury (in the event it is not a bench trial), counsel for the parties, perhaps the other parties, and anyone observing in the courtroom. He is the recipient of attention and the respect - ensured, in this context, by the presiding judgeof all individuals who are present, likely a total change in the dynamics from when he was an H-2A worker. He shares his story, and even if an interpreter is being used, observers in the courtroom would still be able to hear the tone of and any emotion in his voice, and observe his mannerisms and expressions in general. Thus, in addition to having the interpreter convey the content of the worker's testimony, the simple act of direct observation further allows the individuals in the courtroom to experience the worker's voice and story.

In addition, the switch from deposition testimony to trial testimony also represents a change in who defines the contours and thus can control the

intend to return home at the end of the visa validity period, rather than stay in the United States. See Bureau of Consular AfFairs, U.S. DeP'T of State, Visa Denials, https://travel.state.gov/content/visas/en/general/denials.html (last visited Aug. 24, 2017) ("INA Section 214(b) - Visa Qualifications and Immigrant Intent" dropdown). A migrant worker with few obvious, permanent ties to his home-e.g., a steady income, owning property, having children/a family of his own - is unlikely to make such a showing. This is especially true with young men from Latin America, which is the demographic of most $\mathrm{H}$ $2 \mathrm{~A}$ workers. Alternatively, a worker may attempt to enter the United States by applying for humanitarian parole, though such a course is also uncertain, because it is intended for situations involving a "significant public benefit" and, at the end of the day, the grant of parole is an entirely discretionary act. See U.S. CiTIZENSHIP AND IMMIGRATION SERVS., DEP'T OF HOMELAND SECURITY, Guidance on Evidence for Certain Types of Humanitarian or Significant Public Benefit Parole Requests, https://www.uscis.gov/humanitarian/humanitarian-parole/guidance-evidence-certain-typeshumanitarian-or-significant-public-benefit-parole-requests (last visited Aug. 24, 2017). Moreover, because U.S. Citizenship and Immigration Services suggests including "[c]ourt documents stating the date and time of the legal proceedings" when applying for parole to participate in a civil case in the United States, it's much less likely that such an application would be approved in the context of a deposition, occurring simply between the parties, as opposed to appearing for a set trial date. See id. ("To Participate in Civil Legal Proceedings in the United States" dropdown). In light of such difficulties, courts have often sided with plaintiffs when the parties have an unresolved dispute as to when and where to conduct depositions of workers, concluding that the plaintiffs are not required to travel to the United States for depositions and may instead be deposed either in their home countries or by other remote means, such as by videoconference. See, e.g., Murillo v. Dillard, No. 1:15-CV-00069GNS, 2017 U.S. Dist. LEXIS 15391, at*4-13 (W.D. Ky. Feb. 3, 2017) (denying defendants' motion for protective order seeking to prohibit plaintiffs from conducting trial depositions in Mexico on the grounds that the defendants' preference for conducting the depositions in Kentucky was significantly outweighed by the burden and expense on plaintiffs, who were impoverished migrant workers with potentially no legal option to migrate to the United States). 
testimony. Specifically, at trial, it would be counsel for the plaintiff who would first question the worker. ${ }^{259}$ Therefore, it is not opposing counsel who decides the focus of the story that is being told, but rather the worker and his attorney, who together engage in a colloquy before the audience in the court in order to present their proof and seek to have the factfinder decide in favor of the worker. Just as with the framing of the story in the complaint, information about the worker and his background can provide useful additional context to the worker's situation and thus provide greater substance to his claims. In speaking directly in court and in front of all who would be present about his experiences and mistreatment, a worker therefore is given an opportunity to amplify his voice and tell his story to a greater extent than at other moments in the course of a civil lawsuit and in ways not available to him as an $\mathrm{H}-2 \mathrm{~A}$ worker in the past.

\section{Beyond Litigation}

While the above discussion provides advocates with strategies for how to litigate $\mathrm{H}-2 \mathrm{~A}$ cases in a client-centered manner, the focus on maximizing client voice need not be confined to those moments alone. Rather, in keeping with the broader strategies used by community lawyers, a

259 Defense counsel would have the opportunity to cross-examine the worker, and therefore control is not entirely removed from the opposing party. This could result in difficult questioning and a focus on sensitive or irrelevant issues, just as in a deposition. However, with the benefit of having already experienced such questioning at a deposition, a worker and his attorney would have a sense of what to expect. Therefore, this concern should be less potent because of the ability to prepare the worker in advance for these issues that may arise during his testimony at trial. Moreover, I am skeptical that cross-examination maintains its same degree of effectiveness, as a strategic matter, with witnesses testifying through an interpreter. In January 2015, I observed several days of testimony in a civil trial brought by $\mathrm{H}-2 \mathrm{~B}$ guestworkers against their former employer and its agents, including testimony by one plaintiff and a third-party worker witness, both of whom testified via an interpreter. While I admit to being a biased observer, I nevertheless found it striking the degree to which an aggressive style of cross-examination by defense counsel fell flat when the courtroom audience had to wait for the interpreter to translate the question, the worker to answer, and the interpreter to then translate the answer. This is but one anecdotal experience, of course. Notably, however, the jury found for the plaintiffs a few weeks later, awarding them $\$ 14$ million in damages. See Kathy Finn, Indian workers win \$14 million in labor trafficking case, REUTERS, Feb. 18, 2015, https://www.reuters.com/article/us-usa-louisianatrafficking/indian-workers-win-14-million-in-u-s-labor-trafficking-case-

idUSKBNOLN03820150219; see also Beth Ethier, Alabama Company Admits Locking Katrina Workers in Squalid Camps, Settles for \$20 Million, SLATE, July 15, 2015, http://www.slate.com/blogs/the_slatest/2015/07/15/signal_international_lawsuit_settlement guest_workers_for_katrina_rebuilding.html (detailing the employer's declaration of bankruptcy after to the Louisiana outcome and the subsequent settlement of related lawsuits that were headed for trial). 
lawsuit can serve as a jumping off point for various other mechanisms to empower H-2A workers. Below, I first discuss the ways in which the settlement of a lawsuit can provide for forward-looking remedies that can maximize voices of all workers, not just the litigants. I then turn to an exploration of the positive indirect effects of litigation for $\mathrm{H}-2 \mathrm{~A}$ workers.

\section{Forward-Looking Remedies}

Because trials are so rare, ${ }^{260}$ it is far more common to resolve a claim through a settlement among the parties, either after direct negotiation, private mediation, or a court-led settlement conference. As a result, it is worth considering the ways in which this frequent end to a civil lawsuit can serve as a way to empower clients, and other similar workers, through the amplification of their voice.

On the surface, settlement would not appear to be a particularly fruitful venue in which to maximize client voice, for at least two reasons. First, the goal of settlement is usually for the plaintiff to receive some sort of compensation from the defendant in exchange for dismissing his claims. In other words, settlement is about money, not about the ability of the plaintiff to tell his story. Moreover, once the key terms - namely, the amount of the payment - are agreed upon, settlement is generally a technical process, with attorneys for both sides drafting the agreement to memorialize the resolution of the case. Such an agreement is often replete with legalese, again implicating the concern with the "dialect" of the legal system. ${ }^{261}$

Nevertheless, settlement does present a unique opening for amplifying a worker's voice. As a starting point, settlement agreements usually operate in a way for employers to suppress, rather than enhance, worker voice. Confidentiality clauses are exceedingly common in civil settlements in general and in employment cases specifically. ${ }^{262}$ The use of such clauses thus represents another method by which disputes are kept out of the public and information about legal violations thus hidden from view. However, in the context of employment disputes, there are numerous decisions that provide authority for arguing against including a confidentiality clause in a settlement agreement. Several courts have concluded that confidentiality clauses are incompatible with the resolution of minimum wage claims under the FLSA, finding it to be contrary to the purpose of the statute to establish minimum workplace standards in the

${ }^{260}$ See supra note 257.

261 See supra note 111.

${ }^{262}$ See, e.g., Gordon, supra note 122, at 440 ("Even when employers settle a matter with a small group of workers, they frequently require the workers to sign a binding confidentiality agreement."). 
United States. ${ }^{263}$ Thus, if a case is being filed in such a jurisdiction, or at least, not in a jurisdiction that has adopted the contrary view, counsel for an $\mathrm{H}-2 \mathrm{~A}$ worker with FLSA minimum wage claims would have a strong argument against the inclusion of a confidentiality clause in the settlement agreement.

If the attorney is successful in this regard, the worker would then be free to talk about the case, both informally and formally, whether through organizing efforts or even in the press. By speaking openly about the mistreatment he experienced and filing a lawsuit to hold the employer responsible for such violations, he can inform others about their rights and remedies under the law, perhaps resulting in those workers taking legal action themselves. The original worker's voice will therefore be maximized, leading to further worker empowerment and possible action by encouraging other workers to consider litigation or alternative means of standing up for their rights. In sum, confidentiality should not be treated as another throwaway settlement term, a "given" that is accepted without any consideration. Rather, its inclusion can have significant consequences on the worker's own voice and the downstream effects that his voice can have on other workers.

An additional way of encouraging broader worker empowerment by settlement is to negotiate for ongoing steps that the employer must take to guard against any future legal violations. The possibilities here are numerous, given that a settlement agreement is largely treated as another contract, with the parties having a great degree of latitude as to what can be bargained for and thus included as a term. ${ }^{264}$ For example, a settlement agreement may require an employer to provide payroll information for its workers for a given period in the future, after execution of the settlement agreement. ${ }^{265}$ While not

${ }^{263}$ See, e.g., Steele v. Staffmark Invs., LLC, 172 F. Supp. 3d 1024, 1030-31 (W.D. Tenn. 2016) (rejecting parties' arguments in favor of a confidentiality clause in a FLSA settlement because of underlying policy purposes of the FLSA and a general presumption of public access to judicial documents); Wolinsky v. Scholastic Inc., 900 F. Supp. 2d 332, 337-41 (S.D.N.Y. 2012) (same); Dees v. Hydrandry, Inc., 706 F. Supp. 2d 1227, 1244-46 (M.D. Fla. 2010) (same).

${ }^{264}$ One exception to this would be the approach to confidentiality in the jurisdictions that find such a term incompatible with the purposes of the FLSA, as described above. See supra note 263 and accompanying text.

265 This was the approach taken in the Kentucky tobacco worker case, with respect to resolution of the claims brought against the workers' former employer. The settlement agreement, which was reviewed and then approved by the court because it involved resolution of FLSA claims, included provisions requiring the employers to affirmatively agree to comply with the FLSA and the $\mathrm{H}-2 \mathrm{~A}$ regulations, to provide pay stubs as required by the H-2A regulations, and to provide a quarterly report to counsel for the plaintiffs documenting compliance with these terms, together with payroll information and sample pay stubs for any H-2A workers employed by the employers for a period of two years. See Settlement Agreement and Release of Claims IIII 7-9, Cruz-Cruz v. McKenzie Farms, No. 05:15-cv-157 (E.D. Ky. Jan. 15, 2016); see also Minute Entry for Telephonic Conference, Cruz-Cruz v. McKenzie Farms, No. 05:15-cv-157 (E.D. Ky. Feb. 5, 2016) (memorializing 
explicitly about worker voice, such a clause ideally benefits future workers so that they do not experience the same violations as the past workers. But even more worker- and voice-oriented provisions could be included. For example, the defendant could be required to affirmatively distribute information about workers' legal rights, perhaps even requiring approval of plaintiff's counsel before doing so. Or the parties could require that the employer adopt a complaint hotline, therefore more easily enabling workers experiencing violations to speak out about the problem. Community lawyering advocates have included such broad, non-monetary provisions in settlement agreements of cases litigated to further campaigns. ${ }^{266}$ Moreover, federal enforcement agencies often include such terms in consent decrees used to resolve cases. ${ }^{267}$ Private litigants should not shy away from terms that require some degree of ongoing compliance, though the decision on whether or not to push for such terms will ultimately come down to careful discussions with the client and will take into account the totality of the circumstances of the negotiation between the parties.

The above suggestions are simply meant as a starting point, to encourage attorneys representing workers to consider the process of settling a civil lawsuit as not merely a substance-less coda at the end of the story that was one worker's case, but rather as a prologue to the sustained empowerment of workers more generally. Ultimately, an attorney is constrained by the reality that the client is the decisionmaker on questions of settlement ${ }^{268}$ and, at the end of the day, the attorney represents and thus owes duties to the specific client, ${ }^{269}$ not other non-client workers. Both of these factors may create dynamics that push against inclusion of forward-looking terms in a settlement agreement. Nevertheless, if the particular plaintiff is

status conference with settling parties regarding motion for approval of settlement agreement); Order Approving Settlement Agreement, Cruz-Cruz v. McKenzie Farms, No. 05:15-cv-157 (E.D. Ky. Feb. 5, 2016) (signed order approving settlement agreement).

${ }^{266}$ See, e.g., Lee, supra note 93, at 1090 (describing use of provisions covering complaint-resolution procedures and translation of materials for non-English speaking employees, among others, as part of settlement of federal lawsuit and National Labor Relations Board complaints in dispute against restaurant); see also Ashar, supra note 121, at 1916 (summarizing settlement terms, including addition of guaranteed sick and vacation days as well as "some measure of job security for [the worker clients] for one year following the execution of the agreement").

${ }^{267}$ See, e.g., Press Release, U.S. EQUAL EMPLOYMENT OPPORTUNITY COMM'N, Consent Decree Entered in EEOC Record-Keeping Suit Against Crothall Services Group, Dec. 16, 2016, https://www.eeoc.gov/eeoc/newsroom/release/12-16-16a.cfm (announcing consent decree that established record-keeping requirements regarding criminal background checks).

${ }^{268}$ See MODEL RULES OF PROF'L CONDUCT R. 1.2(a) (“A lawyer shall abide by a client's decision whether to settle a matter.").

${ }^{269}$ See, e.g., id. $1.7 \mathrm{cmt}$. (citing "loyalty" to a client as an "essential element[]" in the representation of a client). 
interested in using the process of litigation as a way to amplify not only his voice, but those of other workers as well, then an attorney should be attentive to that desire and consider this moment as another opportunity to do so.

\section{Indirect Effects of Litigation}

Litigation can also be empowering to workers because of the outcomes it has beyond the particular case and resolution of the claims before the court. Such "indirect effects" of litigation, as this has been labeled by one scholar, include "framing grievances in justice terms, conferring legitimacy on a movement's claims, generating favorable publicity, raising consciousness among a movement's constituency, and fostering empowerment." 270 Others have recognized the value that such participation in the legal system can have on the litigants. For example, litigation can be meaningful for clients because it "give[s] them the formal standing to be heard regarding breaches of their legal rights and claims for judicial intervention" and it can "confirm that the conditions of their lives are not fair and give them hope that things need not remain as they have always been."271 Litigation can also help foster group solidarity through the storytelling that emerges in the course of a lawsuit. ${ }^{272}$

Both of the community lawyering case studies described above ${ }^{273}$ highlight these indirect effects achieved by the litigation on behalf of day laborers and restaurant workers. They tell the stories of alliances built and power mobilized in Los Angeles ${ }^{274}$ and the increased sense of solidarity among workers in New York. ${ }^{275}$ Litigation with H-2A workers can achieve similar effects. H-2A workers are perhaps the ultimate "disenfranchised workforce." 276 The United States and its residents rely on their labor to sustain this nation through the food they harvest, but in exchange for this exploitation of labor, the workers get nothing in return. The workers have no real legal ties to the United States - no path to citizenship, regardless of how many years they may have worked in the United States on an H-2A visa-

${ }^{270}$ Cummings, supra note 204, at 1622-23.

${ }^{271}$ White, supra note 129 , at 545.

272 See Delgado, supra note 241, at 2437.

273 See supra section III(A).

274 See supra note 215 and accompanying text.

${ }^{275}$ See supra notes 202-203 and accompanying text. Similarly, in a forthcoming article, Jennifer Lee writes about "undocumented work resistance" and the value that such recognition and inclusion of undocumented workers can have on a group of individuals who are so often are forced to operate at the margins of society. See Jennifer J. Lee, Redefining the Legality of Undocumented Work, 106 CAL. L. REV. (forthcoming 2018) (manuscript at 25, available at https://papers.ssrn.com/sol3/papers.cfm?abstract id=3040872).

${ }^{276}$ Smith, supra note 19 , at 385 n.53. 
and no ability to participate directly in the political processes that affect their legal rights while in the United States. ${ }^{277}$ The very opportunity to participate in the legal process to vindicate their rights marks a significant shift for $\mathrm{H}$ 2A workers: they are having their voices and stories heard, ${ }^{278}$ and, as civil litigants, are on an even playing field with some of the most powerful persons and entities in this country. ${ }^{279}$

Perhaps the value of litigation can best be understood when considering the potential costs of losing it. A recent article extensively details the use of mandatory arbitration clauses in the guestworker context. ${ }^{280}$ It goes without saying that the normative arguments for including and enforcing such clauses in contracts with $\mathrm{H}-2 \mathrm{~A}$ workers deserve significant scrutiny: when workers do not bargain over the contractual terms, do not receive a contract in a language they understand (if they receive one at all), and are generally unfamiliar with the U.S. legal system, the notion that the workers have consented to any such terms borders on the absurd. ${ }^{281}$ Regardless, if a mandatory arbitration term is to be included in a contract and enforced by an adjudicator, the consequences such a decision would have on the transparency of the process and, ultimately, the workers' ability to use their voice would be significant. Generally a "private process," the outcomes of arbitration proceedings "are not recorded, compiled, or publicly available." 282 Moreover, there is no guarantee the arbitrator will "produce written decisions explaining their reasoning," there are usually limitations on discovery, and decisions of arbitrators are open to judicial review in only "extremely narrow" circumstances, with any awards being "final and binding." 283 In other words, the legal violations are buried and the voices and stories of the workers are silenced. H-2A workers, in such a scenario, would be robbed of a chance to assert themselves, their status as outsiders and on the fringes of society reinforced by employers seeking to keep everything as quiet and hidden as possible.

277 See, e.g., id. ("Guestworkers are also a disenfranchised workforce-they cannot participate in the political process and the visa does not provide a means to ever gain citizenship."); Lee, supra note 129, at 42 (“[S]ince H-2 visas are temporary and do not provide a path to lawful permanent residency, guest workers are a de facto underclass of immigrant workers who lack the benefits that come with integrating into U.S. society.").

${ }^{278}$ See supra note 220 and accompanying text (summarizing procedural justice theories and emphasis on perceptions of fairness therein).

${ }^{279}$ See supra note 236 and accompanying text (noting that most litigants in federal court are corporate entities).

${ }^{280}$ See Smith, supra note 19.

${ }^{281}$ See id. at 403-04 (discussing the "consent myth" in the guestworker context).

${ }^{282}$ Id. at 394.

${ }^{283} \mathrm{Id}$. 


\section{CONCLUSION}

$\mathrm{H}-2 \mathrm{~A}$ workers, in many ways, represent the ultimate outsiders in the U.S. legal system: their presence and participation in U.S. society is limited to being temporary agricultural laborers, a role that is facilitated by a program, the very framework of which creates the conditions for the workers' exploitation. Mistreatment of workers is common, and the available legal remedies for such violations are limited. Litigation may not be a perfect solution to these problems. It is an unpredictable and often slow process, generally focused on remedying past harms instead of harnessing power to keep such harms from happening in the future. Nevertheless, because of their outsider status, both as a legal and as a practical matter, litigation often represents the only available avenue for $\mathrm{H}-2 \mathrm{~A}$ workers to take legal action for violations of their rights. Despite it being the only viable option for $\mathrm{H}-2 \mathrm{~A}$ workers to seek a remedy, litigation need not be the exclusionary, lawyerdominated experience that it can so often become with marginalized communities as clients. Quite the opposite - it is possible for advocates representing $\mathrm{H}-2 \mathrm{~A}$ workers to do so in a client-centered manner, taking care to ensure that $\mathrm{H}-2 \mathrm{~A}$ workers understand the process of litigation and are given as many opportunities as possible to tell their story along the way. By focusing on amplifying worker voice in the course of a lawsuit, an attorney representing such workers can empower the workers and also expose the abuses in and inherent flaws of the H-2A program as a whole. In so doing, the attorney can ensure that the workers are no longer nameless figures, asked to return home when this country no longer has any use for their labor, but empowered individuals, part of a broader community of workers standing up for their rights. 